\title{
Reactive nitrogen in Mexico City and its relation to ozone-precursor sensitivity: results from photochemical models
}

\author{
S. Sillman ${ }^{1}$ and J. J. West ${ }^{2}$ \\ ${ }^{1}$ University of Michigan, Ann Arbor, Michigan, USA \\ ${ }^{2}$ University of North Carolina, Chapel Hill, North Carolina, USA \\ Received: 25 September 2008 - Published in Atmos. Chem. Phys. Discuss.: 9 December 2008 \\ Revised: 15 May 2009 - Accepted: 21 May 2009 - Published: 2 June 2009
}

\begin{abstract}
We use results of a 3-D photochemistry/transport model for ozone formation in Mexico City during events in 1997 to investigate ambient concentrations of reactive nitrogen in relation to ozone-precursor sensitivity. Previous results from other locations suggest that ratios such as $\mathrm{O}_{3} / \mathrm{NO}_{\mathrm{y}}$ and $\mathrm{H}_{2} \mathrm{O}_{2} / \mathrm{HNO}_{3}$ might provide measurement-based indicators for $\mathrm{NO}_{\mathrm{x}}$-sensitive or VOC-sensitive conditions. Mexico City presents a different environment due to its high concentrations of VOC and high level of pollutants in general. The model predicts a correlation between PAN and $\mathrm{O}_{3}$ with relatively high $\mathrm{PAN} / \mathrm{O}_{3}(0.07)$, which is still lower than measured values. The model PAN is comparable with results from a model for Paris but much higher than were found in Nashville in both models and measurements. The difference is due in part to the lower temperature in Mexico City relative to Nashville. Model $\mathrm{HNO}_{3}$ in Mexico City is unusually low for an urban area and $\mathrm{PAN} / \mathrm{HNO}_{3}$ is very high, probably due to the high ratio of reactivity-weighted VOC to $\mathrm{NO}_{\mathrm{x}}$. The model predicts that VOC-sensitive chemistry in Mexico is associated with high $\mathrm{NO}_{\mathrm{x}}, \mathrm{NO}_{\mathrm{y}}$ and $\mathrm{NO}_{\mathrm{x}} / \mathrm{NO}_{\mathrm{y}}$ and with low $\mathrm{O}_{3} / \mathrm{NO}_{\mathrm{y}}$ and $\mathrm{H}_{2} \mathrm{O}_{2} / \mathrm{HNO}_{3}$, suggesting that these indicators work well for Mexico City. The relation between ozone-precursor sensitivity and either $\mathrm{O}_{3} / \mathrm{NO}_{\mathrm{z}}$ or $\mathrm{O}_{3} / \mathrm{HNO}_{3}$ is more ambiguous. VOC-sensitive conditions are associated with higher $\mathrm{O}_{3} / \mathrm{HNO}_{3}$ than would be found in $\mathrm{NO}_{\mathrm{x}}$-sensitive conditions, but model $\mathrm{O}_{3} / \mathrm{HNO}_{3}$ associated with both $\mathrm{NO}_{\mathrm{x}}-$ sensitive and VOC-sensitive chemistry is higher in Mexico than in other cities. The model predicts a mixed pattern of ozone-precursor sensitivity in Mexico City, with VOCsensitive conditions in the morning and $\mathrm{NO}_{\mathrm{x}}$-sensitive in the afternoon, in contrast to results from other models for more recent events that predicted strongly VOC- sensitive conditions throughout the day. The difference in predicted ozone-
\end{abstract}

Correspondence to: S. Sillman (sillman@umich.edu) precursor sensitivity is most likely due to different emission rates and to changes in emissions over time. The model with mixed sensitivity predicts much lower ambient $\mathrm{NO}_{\mathrm{x}}$ and $\mathrm{NO}_{\mathrm{x}} / \mathrm{NO}_{\mathrm{y}}$ than the strongly VOC-sensitive model.

\section{Introduction}

The relation between ozone and its two main precursors, volatile organic compounds (VOC) and nitrogen oxides $\left(\mathrm{NO}_{\mathrm{x}}\right)$, remains a major source of uncertainty in polluted regions. It is generally known that for some conditions the rate of ozone production increases with increasing $\mathrm{NO}_{\mathrm{x}}$, while for other conditions ozone production decreases with increasing $\mathrm{NO}_{\mathrm{x}}$ and increases with VOC. However it is difficult to determine which conditions are prevalent for individual urban areas. As a result it is often difficult to develop effective control strategies for reducing ambient ozone.

Ozone-precursor sensitivity is usually determined based on results of 3-dimensional chemistry/transport models, but the model predictions are subject to considerable uncertainty. Predicted $\mathrm{O}_{3}-\mathrm{NO}_{\mathrm{x}}-\mathrm{VOC}$ sensitivity is sensitive in particular to emission rates for $\mathrm{NO}_{\mathrm{x}}$ and $\mathrm{VOC}$, the assumed reactivity of VOC emissions and the photochemical representation. It is especially difficult to derive methods for evaluating the accuracy of model sensitivity predictions. Models are routinely evaluated in comparison with ambient $\mathrm{O}_{3}$, but it is frequently possible to generate similar $\mathrm{O}_{3}$ in model scenarios with opposite results for $\mathrm{O}_{3}$-precursor sensitivity (e.g. Pierce et al., 1998).

In recent years efforts have been made to derive information about ozone-precursor sensitivity directly from ambient measurements. These "observation-based methods" provide a way to corroborate or refute the predictions for $\mathrm{O}_{3}$ precursor sensitivity from models and also provide ways to evaluate model performance that are linked to the accuracy of the model sensitivity predictions. These methods include

Published by Copernicus Publications on behalf of the European Geosciences Union. 
evaluations based on ambient $\mathrm{NO}_{\mathrm{x}}$ and $\mathrm{VOC}$ (e.g. Kleinman et al., 2005), methods based on the difference between weekday and weekend $\mathrm{O}_{3}$ (Stephens et al., 2008) and methods based on reactive nitrogen and peroxides (Sillman, 1995; Sillman and $\mathrm{He}, 2002)$. Methods based on direct measurement of $\mathrm{HO}_{2}$ radicals are also in preparation based on work described in Thornton et al. (2002) and Shirley et al. (2006).

Here, we focus on the predicted behavior of reactive nitrogen and peroxides in the Mexico City region. Previous results have shown that species ratios and correlations between $\mathrm{O}_{3}$, reactive nitrogen and peroxides show distinctly different patterns for $\mathrm{NO}_{\mathrm{x}}$-saturated (VOC-sensitive) conditions as opposed to $\mathrm{NO}_{\mathrm{x}}$-sensitive conditions, and that the patterns appear to be similar for many urban areas in the US and in Europe. When predicted species ratios and correlations are different for $\mathrm{NO}_{\mathrm{x}}$-sensitive and VOC-sensitive conditions, then comparisons with measured values can provide an indirect evaluation of the accuracy of model ozone-precursor sensitivity. By contrast, when predicted species correlations show similar patterns for both $\mathrm{NO}_{\mathrm{x}}$-sensitive and VOC-sensitive environments, then model agreement with measured values may not provide a basis for evaluating the accuracy of model sensitivity predictions.

Air pollution in Mexico has been the subject of intense study in recent years (e.g. Molina et al., 2007). Conditions in Mexico City differ from other urbanized regions in many ways, including emission rates, VOC speciation, ambient temperatures and photolysis rates (due to altitude). As a result the cycling of reactive nitrogen and its relation to odd hydrogen radicals can be very different from other locations. We will evaluate the predicted correlations among secondary species in Mexico City from a 3-D photochemical model in contrast to results obtained from models and measurements in other cities, and determine whether these correlations are good predictors of $\mathrm{O}_{3}-\mathrm{NO}_{\mathrm{x}}-\mathrm{VOC}$ sensitivity. Results will be used to identify measurements that might resolve the uncertain relation between ozone and precursors in Mexico City.

\section{Background}

Correlations between secondary reaction products in photochemically active regions reflect several different processes: background concentrations for each species, relative rates of photochemical production within the region, photochemical lifetimes and other removal processes. In regions where photochemical production dominates, correlations between species may provide an evaluation of model photochemistry.

For gas-phase species related to $\mathrm{O}_{3}$, three different processes dominate. Peroxides are produced by the reactions

$$
\begin{aligned}
& \mathrm{HO}_{2}+\mathrm{HO}_{2} \rightarrow \mathrm{H}_{2} \mathrm{O}_{2} \\
& \mathrm{HO}_{2}+\mathrm{RO}_{2} \rightarrow \mathrm{ROOH}
\end{aligned}
$$

where $\mathrm{RO}_{2}$ and $\mathrm{ROOH}$ represent hydrocarbon chains ending in $-\mathrm{O}_{2}$ and $-\mathrm{OOH}$ respectively (for example, $\mathrm{CH}_{3} \mathrm{O} 2$ and $\mathrm{CH}_{3} \mathrm{OOH}$ ). Nitric acid is produced by

$\mathrm{OH}+\mathrm{NO}_{2} \rightarrow \mathrm{HNO}_{3}$

$\mathrm{O}_{3}$ is produced by a reaction sequence initiated by reactions with the form

$\mathrm{OH}+\mathrm{VOC} \rightarrow \mathrm{RO}_{2}$

followed by

$\mathrm{RO}_{2}+\mathrm{NO} \rightarrow \mathrm{NO}_{2}+$ products

$\mathrm{NO}_{2}$ then photolyzes to produce $\mathrm{O}_{3}$. Other species, including PAN and other organic nitrates, are produced by similar reaction sequences.

The contrast between $\mathrm{NO}_{\mathrm{x}}$-sensitive and VOC-sensitive photochemistry is closely related to the relative rates of formation of peroxides (R1a and b) and nitric acid (R2), both of which are sinks for odd hydrogen radicals and thus indirectly affect the rate of ozone formation (Sillman, 1995; Kleinman et al., 1997; Kleinman, 2005; Thornton et al., 2002). Consequently, a high value for the ratio $\mathrm{H}_{2} \mathrm{O}_{2} / \mathrm{HNO}_{3}$ is associated with $\mathrm{NO}_{\mathrm{x}}$-sensitive photochemistry and a low value is associated with VOC-sensitive photochemistry. Rates of formation of ozone (R3 and R4) and nitric acid (R2) also reflect differences in photochemistry, and the correlation between these species may also reflect differences in $\mathrm{O}_{3}-\mathrm{NO}_{\mathrm{x}}-\mathrm{VOC}$ sensitivity, although less directly than $\mathrm{H}_{2} \mathrm{O}_{2} / \mathrm{HNO}_{3}$.

The relation between $\mathrm{O}_{3}$ and PAN is fundamentally different from the relation between $\mathrm{O}_{3}$ and $\mathrm{HNO}_{3}$. PAN is produced by the reaction

$$
\mathrm{OH}+\mathrm{CH}_{3} \mathrm{CHO} \rightarrow \mathrm{CH}_{3} \mathrm{CO}_{3}
$$

followed by

$$
\mathrm{CH}_{3} \mathrm{CO}_{3}+\mathrm{NO}_{2} \rightarrow \mathrm{PAN}
$$

The PAN precursor acetaldehyde $\left(\mathrm{CH}_{3} \mathrm{CHO}\right)$ is produced from the oxidation of primary $\mathrm{VOC}$ in the presence of $\mathrm{NO}_{\mathrm{x}}$ and is also emitted directly. Similar reaction sequences occur for other PAN precursors (such as methylglyoxal). This sequence is analogous to Reactions (R3) and (R4), leading to ozone formation. Consequently, ambient $\mathrm{O}_{3}$ is expected to correlate with PAN but the correlation is not related to $\mathrm{O}_{3}-\mathrm{NO}_{\mathrm{x}}-\mathrm{VOC}$ sensitivity (Sillman et al., 2002). In addition, at warm temperatures PAN and $\mathrm{CH}_{3} \mathrm{CO}_{3}$ approach a steady state value with PAN proportional to $\mathrm{O}_{3}$ (Sillman et al., 1990). For $\mathrm{NO}_{\mathrm{x}}$ mixing ratios of $1 \mathrm{ppb}$ or higher the dominant removal sequence for PAN is

$\mathrm{PAN} \rightarrow \mathrm{CH}_{3} \mathrm{CO}_{3}+\mathrm{NO}_{2}$

followed by

$\mathrm{CH}_{3} \mathrm{CO}_{3}+\mathrm{NO} \rightarrow \mathrm{CH}_{3} \mathrm{O}_{2}+\mathrm{NO}_{2}+\mathrm{CO}_{2}$ 
The steady state concentration of PAN resulting from (R5), (R6), (R7) and (R8) is

$[\mathrm{PAN}]=\frac{k_{5} k_{6}}{k_{7} k_{8}}\left(\frac{\mathrm{NO}_{2}}{\mathrm{NO}}\right)[\mathrm{OH}]\left[\mathrm{CH}_{3} \mathrm{CHO}\right]$

where $k_{n}$ represents the rate for reaction $n$. The ratio $\mathrm{NO}_{2} / \mathrm{NO}$ forms a steady state with $\mathrm{O}_{3}$ and is proportional to $\mathrm{O}_{3}$ (e.g. Cantrell et al., 1992). PAN is therefore expected to increase with $\mathrm{O}_{3}$, and the ratio $\mathrm{PAN} / \mathrm{O}_{3}$ should increase in proportion to local photochemical productivity.

\section{Model description and application}

Here we analyze the model simulations of the Mexico City Metropolitan Area by West et al. (2004). West et al. (2004) used the CIT model of atmospheric chemistry and transport, with the SAPRC-99 chemical mechanism (Carter, 2000), and using meteorological inputs from previous modeling using the Regional Atmospheric Modeling System (RAMS, Fast and Zhong, 1998). The model was applied to six two-day periods during the IMADA measurement campaign in March of 1997, where the model was allowed to initialize during the first day of each pair, and results were analyzed on the second day. The model horizontal domain was $85.5 \times 90 \mathrm{~km}$ with $4.5 \mathrm{~km}$ resolution. The model had 15 vertical layers extending to $4.6 \mathrm{~km}$ above the surface.

Model predictions of VOCs, $\mathrm{CO}$, and $\mathrm{NO}_{\mathrm{x}}$ were compared with surface measurements of these species, and on the basis of this comparison, emissions of VOCs were increased by a factor of three relative to the official Mexico City inventory, and of $\mathrm{CO}$ by a factor of two. The model predicted $\mathrm{NO}_{\mathrm{x}}$ concentrations well, particularly with little bias during the daytime. The increases in VOC and $\mathrm{CO}$ emissions were supported by other results using $\mathrm{VOC} / \mathrm{NO}_{\mathrm{x}}$ and $\mathrm{CO} / \mathrm{NO}_{\mathrm{x}}$ ratios over many years (Arriaga-Colina et al., 2004). With these corrections, the model reproduced both the spatial pattern and timing of ozone concentrations well overall, and particularly on 2, 4, and 14 March.

On 4 March 1997, winds were from the north and sustained during the day. Peak concentrations of ozone over the city occurred early in the day $(12-13 \mathrm{~h})$, while the overall predicted peak concentration occurred south of the city at $14-15 \mathrm{~h}$. These results agree with ozone measurements that show that the peak occurred early in the city center, and later south of the city. We also show results for 2 March, a day characterized by light and variable winds and somewhat higher ozone. Afternoon winds from the south blew the peak ozone back over the city, such that the peak concentrations occurred over the city at $13-15 \mathrm{~h}$ (in contrast with 4 March). Model results also agreed with measured peak $\mathrm{O}_{3}$ both in terms of geographical distribution and the absolute peak (235 ppb measured, $199 \mathrm{ppb}$ modeled). Lastly, 14 March was characterized by lower afternoon temperatures (22-24 ${ }^{\circ} \mathrm{C}$ in contrast to $27^{\circ} \mathrm{C}$ ), south winds and peak $\mathrm{O}_{3}$ to the north of the city. The model underestimated peak $\mathrm{O}_{3}$ on this day (164 ppb at $14-15 \mathrm{~h}$ modeled, $201 \mathrm{ppb}$ at $15-16 \mathrm{~h}$ measured), but the model average $\mathrm{O}_{3}$ over all measurement sites during the afternoon agreed with the measured average to within a few ppb.

West et al. (2004) reported extensive comparisons between model results and measured $\mathrm{O}_{3}, \mathrm{VOC}$ and $\mathrm{NO}_{\mathrm{y}}$ during the event. They found generally good agreement for these species following their adjustment in emission rates. West et al. (2004) also compared model results with previous measurements of PAN (Gaffney et al., 1999) and total nitric acid (gas phase $\mathrm{HNO}_{3}$ plus particulate nitrate, Chow et al., 2002). They found that model PAN was lower than the average measurements by a factor of two, while total nitric acid was only slightly underestimated (26\%).

Because of the small size of the model domain, the results may be especially sensitive to boundary conditions. The results also will not include the effect of ozone production and precursor emissions at the regional scale and upwind from Mexico City. West et al. (2004) reported that boundary conditions had relatively little impact on model VOC in the Mexico City urban center. However, results for locations outside the urban center and downwind plume may be sensitive to boundary conditions.

\section{Results}

\subsection{Comparison between Mexico City, Paris and Nashville}

Figure 1 shows model correlations for $\mathrm{O}_{3}$ versus $\mathrm{NO}_{\mathrm{x}}$ reaction products $\left(\mathrm{NO}_{\mathrm{y}}-\mathrm{NO}_{\mathrm{x}}\right.$, or $\left.\mathrm{NO}_{\mathrm{z}}\right)$ for the ensemble of model locations in Mexico City at 13-14 h and 15-16 h on 4 March. The correlation shows surface values of $\mathrm{O}_{3}$ versus $\mathrm{NO}_{z}$ for the entire model domain, which includes both Mexico City and the surrounding rural area. The figure also shows equivalent correlations from model-based studies in two different locations: Nashville (Sillman et al., 1998) and Paris (Sillman et al., 2003). The previous studies also included comparisons with measured $\mathrm{O}_{3}$ versus $\mathrm{NO}_{z}$ for the model events and generally good agreement. Results are also shown for $\mathrm{HNO}_{3}$, PAN and other organic nitrates. The Nashville model results for PAN are also consistent with the measured correlations between $\mathrm{O}_{3}$ and PAN in the region reported by Roberts et al. (1998). Measured $\mathrm{HNO}_{3}$ was not available for comparison in the previous studies.

Resuts show that the model correlation for $\mathrm{O}_{3}$ versus summed $\mathrm{NO}_{z}$ in Mexico is similar to correlations in Nashville and in Paris. There is also little change in the correlation between $13-14 \mathrm{~h}$ and $15-16 \mathrm{~h}$. Because this correlation is associated with the ozone production efficiency per $\mathrm{NO}_{\mathrm{x}}$ (e.g. Trainer et al., 1993), this result suggests that the ozone production efficiency in Mexico City is similar to other locations. However, the results are very different for 

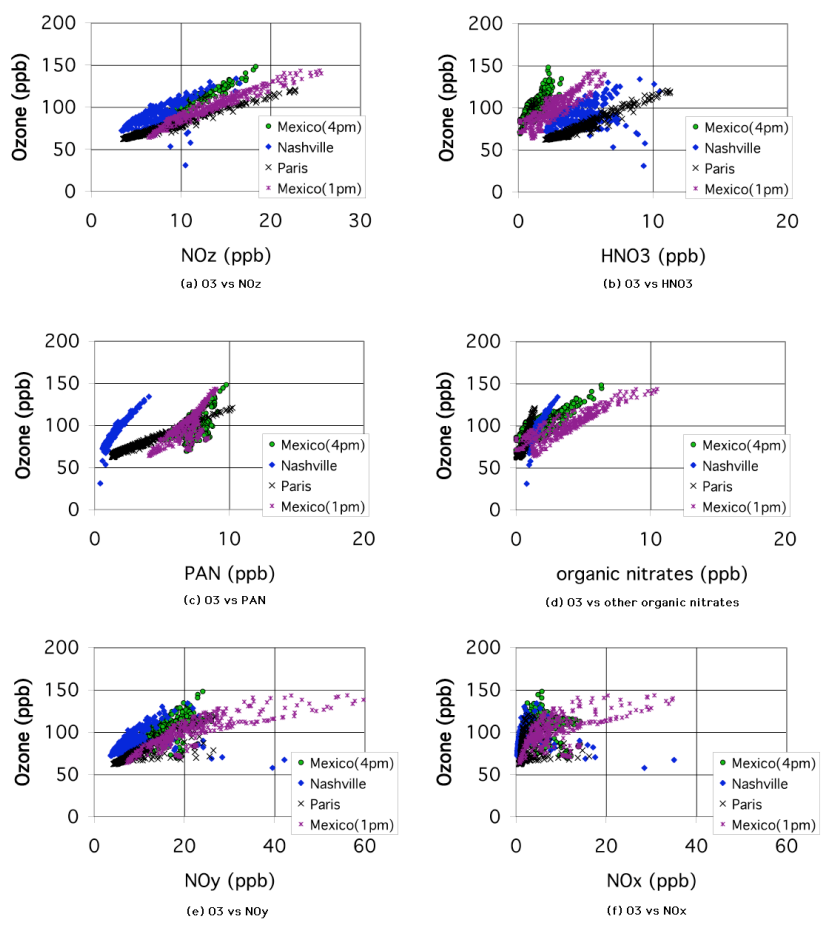

Fig. 1. Model $\mathrm{O}_{3}$ vs. reactive nitrogen in $\mathrm{ppb}$ at four locations: Mexico City on 4 March 1997 at 12-13 h LT (purple asterisks), and 15-16 h (green circles), Nashville (blue diamonds) and Paris (X's). Results are shown for (a) summed $\mathrm{NO}_{\mathrm{x}}$ reaction products $\left(\mathrm{NO}_{\mathrm{Z}}\right)$, (b) $\mathrm{HNO}_{3}$, (c) PAN (d) other organic nitrates, (e) summed total reactive nitrogen $\left(\mathrm{NO}_{y}\right)$, and (f) $\mathrm{NO}_{\mathrm{x}}$.

correlations involving specific reaction products. Results for $\mathrm{O}_{3}$ versus $\mathrm{HNO}_{3}$ show a positive correlation between the two species at each location but with different $\mathrm{O}_{3} / \mathrm{HNO}_{3}$ ratios. The $\mathrm{O}_{3} / \mathrm{HNO}_{3}$ ratio is lowest for Paris, somewhat higher for Nashville, and much higher in the model for Mexico. The $\mathrm{O}_{3} / \mathrm{HNO}_{3}$ ratio for Mexico also changes between 13$14 \mathrm{~h}$ and $15-16 \mathrm{~h}$ at the locations with highest $\mathrm{O}_{3}$, increasing from 20 at $13-14 \mathrm{~h}$ to 50 at $15-16 \mathrm{~h}$. By contrast the model $\mathrm{O}_{3} / \mathrm{HNO}_{3}$ associated with peak $\mathrm{O}_{3}$ is 10 for Paris and 14 for Nashville. $\mathrm{HNO}_{3}$ represents approximately $50 \%$ of total $\mathrm{NO}_{\mathrm{Z}}$ in Paris and in Nashville but just $20 \%$ in Mexico City.

Significant differences among the three locations also appear for PAN. Absolute modeled concentrations of PAN are comparable in Mexico and Paris, and are significantly higher than in Nashville. The model PAN is approximately $50 \%$ lower than the average from an ensemble of measurements at one station in Mexico City (Gaffney et al., 1999). High concentrations of PAN were also reported in model results by Lei et al. (2007). The $\mathrm{O}_{3} / \mathrm{PAN}$ ratio is much higher for Nashville than for the other cities. $\mathrm{O}_{3} / \mathrm{PAN}$ ratios are similar for Paris and Mexico, although the slope between $\mathrm{O}_{3}$ and PAN is lower for Paris. Results for Mexico are similar at 13-14 h and 15-16 h on 4 March, although on 2 March the $\mathrm{O}_{3}$-PAN correlation for Mexico showed greater scatter. The measurements from Gaffney et al. (1999) showed a loose correlation between $\mathrm{PAN}$ and $\mathrm{O}_{3}$ with an average $\mathrm{PAN} / \mathrm{O}_{3}$ ratio equal to .12 for $\mathrm{O}_{3}$ above $100 \mathrm{ppb}$. The model $\mathrm{PAN} / \mathrm{O}_{3}$ is significantly lower (.07) but the measured PAN, $\mathrm{O}_{3}$, and $\mathrm{PAN} / \mathrm{O}_{3}$ still fall within the range of measured values. Results for other organic nitrates showed much higher concentrations in relation to $\mathrm{O}_{3}$ for Mexico than for either Nashville or Paris.

The correlation between $\mathrm{O}_{3}$ and $\mathrm{NO}_{\mathrm{y}}$ is weaker than the correlation between $\mathrm{O}_{3}$ and $\mathrm{NO}_{\mathrm{x}}$ reaction products. The model correlation for Mexico at $15-16 \mathrm{~h}$ is comparable to the model results for Nashville and Paris. All three cases show $\mathrm{O}_{3}$ generally increasing with $\mathrm{NO}_{\mathrm{y}}$ and a similar range of values, and all three cases include some locations with much lower $\mathrm{O}_{3} / \mathrm{NO}_{\mathrm{y}}$, probably reflecting fresh $\mathrm{NO}_{\mathrm{x}}$ emissions. The correlation for Mexico at 13-14 h differs in that it includes a number of locations with high $\mathrm{O}_{3}$ and much higher $\mathrm{NO}_{\mathrm{x}}$. At the other sites and at Mexico at $16 \mathrm{~h}$ the highest $\mathrm{O}_{3}$ is associated with 20-25 ppb NO ico at $14 \mathrm{~h}$ the highest $\mathrm{O}_{3}$ is associated with $\mathrm{NO}_{\mathrm{y}}$ between 25 and $50 \mathrm{ppb}$. The $\mathrm{O}_{3} / \mathrm{NO}_{\mathrm{y}}$ ratio associated with high $\mathrm{O}_{3}$ is also much lower. The high $\mathrm{NO}_{\mathrm{y}}$ in Mexico at $14 \mathrm{~h}$ is due to larger $\mathrm{NO}_{\mathrm{x}}$ and lower rates of photochemical processing (related to $\mathrm{NO}_{\mathrm{x}} / \mathrm{NO}_{\mathrm{y}}$ ). $\mathrm{O}_{3}$ generally increases with $\mathrm{NO}_{\mathrm{y}}$ for $\mathrm{NO}_{\mathrm{y}}$ below $25 \mathrm{ppb}$ but not for higher $\mathrm{NO}_{\mathrm{y}}$.

There is little correlation between $\mathrm{O}_{3}$ and $\mathrm{NO}_{\mathrm{x}}$ at any of the sites, and the highest $\mathrm{O}_{3}$ is often associated with relatively low $\mathrm{NO}_{\mathrm{x}}$. In Paris and Nashville the highest $\mathrm{O}_{3}$ is found in downwind locations following removal of $\mathrm{NO}_{\mathrm{x}}$. Mexico at $16 \mathrm{~h}$ shows this pattern, and peak $\mathrm{O}_{3}$ in Mexico is associated with $6 \mathrm{ppb} \mathrm{NO}_{\mathrm{x}}$. Mexico at $14 \mathrm{~h}$ shows a different pattern. At that time $\mathrm{O}_{3}$ is predicted to increase with $\mathrm{NO}_{\mathrm{x}}$ and $\mathrm{NO}_{\mathrm{x}}$ associated with peak $\mathrm{O}_{3}$ ranges from 6 to $20 \mathrm{ppb}$.

\subsection{Ambient species and ozone-precursor sensitivity}

Model predictions for $\mathrm{O}_{3}$-precursor sensitivity are derived by repeating the original model scenario (a) with a $50 \%$ reduction in emission of anthropogenic hydrocarbons and (b) with a $50 \%$ reduction in anthropogenic $\mathrm{NO}_{\mathrm{x}}$. The resulting change in $\mathrm{O}_{3}$ at each model location relative to the initial scenario is shown in Fig. 2 for 2 March, 12-13 h and 15-16h. As shown in the figure, the response to reduced VOC and $\mathrm{NO}_{\mathrm{x}}$ varies greatly with the time of day and model location. At some locations $\mathrm{O}_{3}$ decreases in response to a reduction in $\mathrm{NO}_{\mathrm{x}}$ but changes little in response to VOC, while at other locations $\mathrm{O}_{3}$ decreases in response to a reduction in VOC but changes little in response to $\mathrm{NO}_{\mathrm{x}}$. Many model locations show a mixed response with reduced $\mathrm{O}_{3}$ in response to reductions in either VOC or $\mathrm{NO}_{\mathrm{x}}$. The main feature of the model sensitivity predictions is a shift from predominantly VOC-sensitive conditions at $12-13 \mathrm{~h}$ to $\mathrm{NO}_{\mathrm{x}}$-sensitive conditions at $15-16 \mathrm{~h}$. A similar shift was predicted for 4 March and 14 March. For $13-14 \mathrm{~h}$ and $14-15 \mathrm{~h}$ the model predicted a mixed response with a roughly equal reduction in $\mathrm{O}_{3}$ 


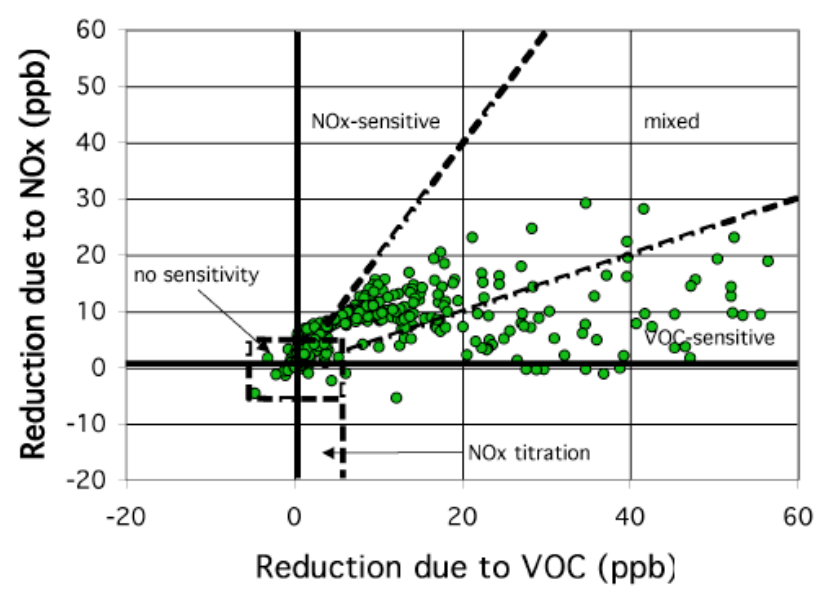

(a) March 2, 1997, 12-13 h

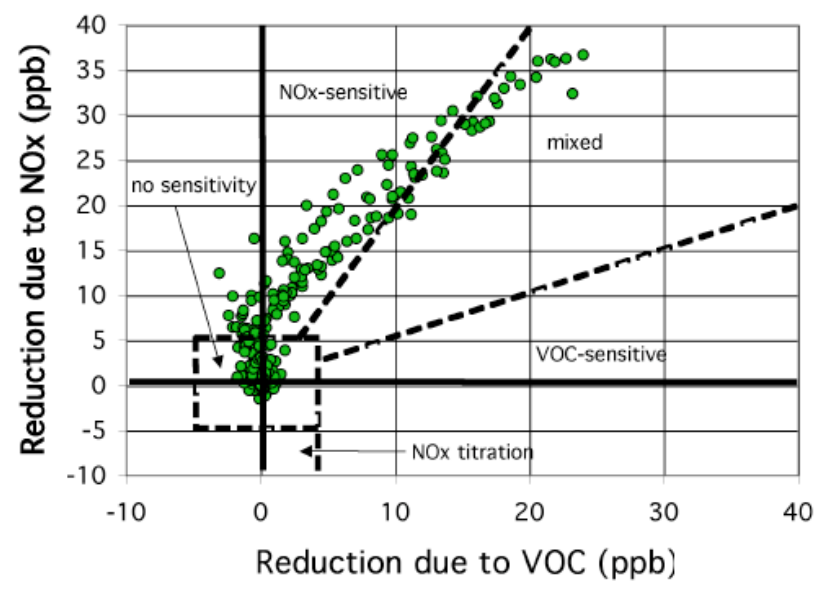

(b) March 2, 1997, 15-16 h

Fig. 2. Predicted reduction in surface $\mathrm{O}_{3}$ in each model horizontal grid resulting from (i) a 50\% reduction in anthropogenic VOC and (ii) a 50\% reduction in $\mathrm{NO}_{\mathrm{x}}$, shown for $2 \mathrm{March}$ at (a) $12-13 \mathrm{~h}$ and (b) $15-16 \mathrm{~h}$. The dashed lines identify the five categories for predicted $\mathrm{O}_{3}-\mathrm{NO}_{\mathrm{x}}-$ VOC sensitivity used in subsequent figures: $\mathrm{NO}_{\mathrm{X}}{ }^{-}$ sensitive, mixed, VOC- sensitive, locations dominated by $\mathrm{NO}_{\mathrm{x}}$ titration, and locations with little sensitivity to $\mathrm{VOC}$ and $\mathrm{NO}_{\mathrm{x}}$ (usually found near the upwind boundary).

resulting from reductions in either $\mathrm{VOC}$ or $\mathrm{NO}_{\mathrm{x}}$. These sensitivity predictions differ from the model results reported by Lei et al. (2007), which found predominantly VOC-sensitive chemistry during a different event, as discussed later.

Although the predicted response to precursor reductions was generally similar for all three days there was an important difference in geographical distribution. On 4 March the highest $\mathrm{O}_{3}$ was found in the plume south of Mexico City. Peak $\mathrm{O}_{3}$ within the city itself occurred at $12-13 \mathrm{~h}$ and was associated with strongly VOC-sensitive conditions in the model. By contrast, on 2 March the ozone plume remained in the city through $15-16 \mathrm{~h}$ so that peak ozone within the city occurred later (13-15 h) and showed sensitivity to both VOC and $\mathrm{NO}_{\mathrm{x}}$. The size of the predicted reduction in $\mathrm{O}_{3}$ generally increases with $\mathrm{O}_{3}$. However, the reductions due to reduced VOC at $12-13 \mathrm{~h}$ tend to be larger than the reductions due to reduced $\mathrm{NO}_{\mathrm{x}}$ at $15-16 \mathrm{~h}$. The latter feature is especially noteworthy on 4 March. Much of the model domain (including urban Mexico City) has moderately high $\mathrm{O}_{3}(100-120 \mathrm{ppb})$ at $15-16 \mathrm{~h}$. Ozone at this hour shows greater sensitivity to $\mathrm{NO}_{\mathrm{x}}$ than to VOC, but even a $50 \%$ reduction in $\mathrm{NO}_{\mathrm{x}}$ is predicted to yield only a small $(5 \%-10 \%)$ reduction in $\mathrm{O}_{3}$ over most of the model domain. The largest reduction due to reduced $\mathrm{NO}_{\mathrm{x}}$ (associated with the highest $\mathrm{O}_{3}$ at 15-16 h) was $18 \%$. By contrast, a $50 \%$ reduction in VOC is predicted to yield a $20 \%-30 \%$ reduction in $\mathrm{O}_{3}$ (including peak $\mathrm{O}_{3}$ ) at $12-$ $13 \mathrm{~h}$, athough reduced VOC had little effect on $\mathrm{O}_{3}$ at $15-16 \mathrm{~h}$.

As will be discussed below, $\mathrm{O}_{3}$-precursor sensitivity predictions are very uncertain and there is contradictory evidence from other models in the case of Mexico. Here we intend to use the sensitivity results to identify specific species concentrations that are associated with $\mathrm{NO}_{\mathrm{x}}$-sensitive or VOC-sensitive photochemistry. This approach has been used extensively before (e.g. Sillman and He, 2002) to provide a basis for evaluating the accuracy of model predictions through a measurement-based program.

In order to evaluate the relation between predicted $\mathrm{O}_{3}$ precursor sensitivity and ambient species concentrations we will use the following definitions, which are also illustrated in Fig. 2. A location is defined as $\mathrm{NO}_{\mathrm{x}}$-sensitive at a given time if $\mathrm{O}_{3}$ at that hour decreases by at least $5 \mathrm{ppb}$ in response to reduced $\mathrm{NO}_{\mathrm{x}}$ and if the decrease in response to reduced $\mathrm{NO}_{\mathrm{x}}$ is at least twice as large as the decrease in response to reduced VOC. A location is defined as VOC-sensitive if $\mathrm{O}_{3}$ decreases by at least $5 \mathrm{ppb}$ in response to reduced VOC and if the decrease in response to reduced VOC is at least twice as large as the decrease in response to reduced $\mathrm{NO}_{\mathrm{x}}$ ( or if $\mathrm{O}_{3}$ increases in response to reduced $\mathrm{NO}_{\mathrm{x}}$ ). A location is defined as having mixed sensitivity if $\mathrm{O}_{3}$ decreases by at least $5 \mathrm{ppb}$ in response to either reduced $\mathrm{VOC}$ or reduced $\mathrm{NO}_{\mathrm{x}}$ and if the decrease in response to reduced VOC and reduced $\mathrm{NO}_{\mathrm{x}}$ differ by less than a factor of two. Lastly, a location is defined as dominated by $\mathrm{NO}_{\mathrm{x}}$ titration if $\mathrm{O}_{3}$ increases by $5 \mathrm{ppb}$ or more in response to reduced $\mathrm{NO}_{\mathrm{x}}$ and does not decrease by $5 \mathrm{ppb}$ or more in response to reduced VOC. The latter condition usually occurs in plumes from large power plants with very high $\mathrm{NO}_{\mathrm{x}}$, low VOC and little photochemical activity other than the removal of $\mathrm{O}_{3}$ through reaction with directly emitted NO. In this study no locations met the definition for $\mathrm{NO}_{\mathrm{x}}$ titration during the time periods shown. Locations that do not show a 5 ppb change in response to either reduced $\mathrm{NO}_{\mathrm{x}}$ or reduced VOC are omitted from the subsequent analysis. Species concentrations at these omitted locations generally represented the model boundary conditions (sometimes combined with direct emissions) with little photochemical processing. Similar definitions were used by Sillman and He (2002). 

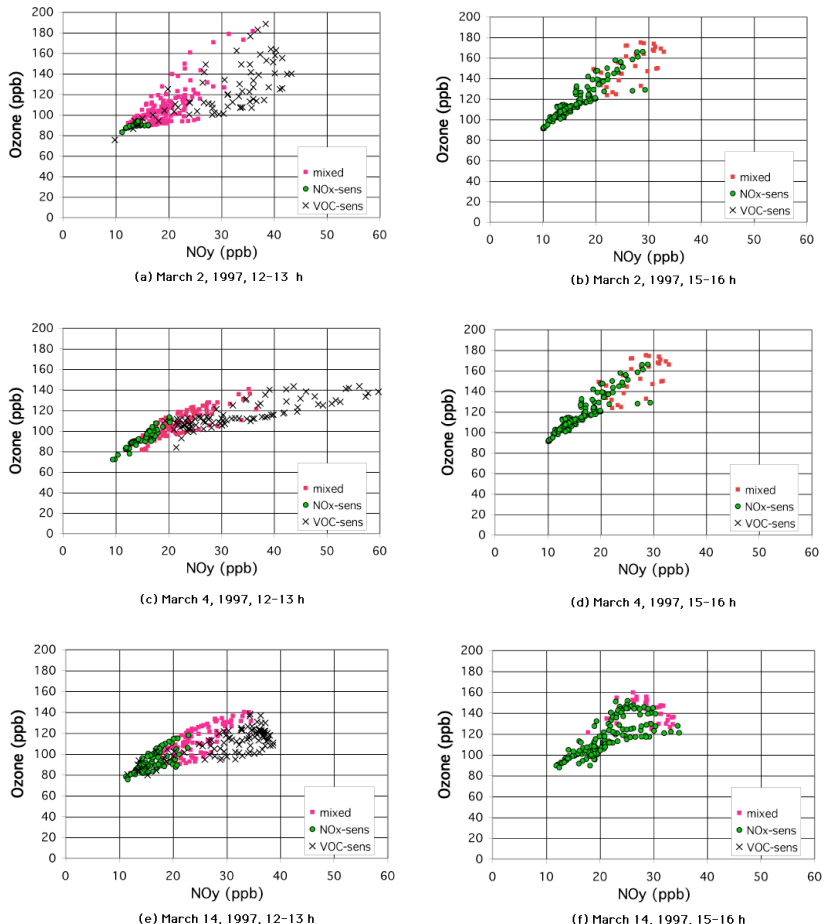

(e) March 14, 1997, 12-13 h

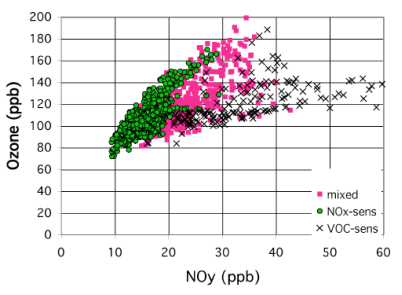

(g) March 2 and 4, 1997, 12-16 h

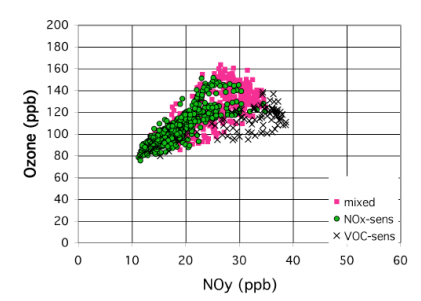

(h) March 14, 1997, 12-16 h

Fig. 3. $\mathrm{O}_{3}$ vs. $\mathrm{NO}_{\mathrm{y}}(\mathrm{ppb})$ sorted by precursor sensitivity. Locations are identified as primarily sensitive to $\mathrm{NO}_{\mathrm{x}}$ (green circles), primarily sensitive to VOC (Xs), and with mixed sensitivity (pink squares). Results are for (a) 2 March, 12-13 h; (b) 2 March, 15$16 \mathrm{~h}$; (c) 4 March, 12-13 h; (d) 4 March, 15-16 h; (e) 14 March, 12-13 h; (f) 14 March, 15-16 h; (g) composite of 4 hourly intervals from $12 \mathrm{~h}$ to $16 \mathrm{~h}$ on 2 and 4 March; and (h) composite of 4 hourly intervals from $12 \mathrm{~h}$ to $16 \mathrm{~h}$ on $14 \mathrm{March}$, all in 1997.

These sensitivity categories are used to characterize the predicted change in ozone in response to reduced $\mathrm{NO}_{\mathrm{x}}$ or VOC at specific hours and will be used in combination with predicted ambient concentrations at the same hour. The sensitivity categories for a given location at one hour do not necessarily apply to other times; some locations change from VOC-sensitive to $\mathrm{NO}_{\mathrm{x}}$-sensitive at different hours (Fig. 2).

Figure 3 shows model $\mathrm{O}_{3}$ versus $\mathrm{NO}_{\mathrm{y}}$ for Mexico City for 2, 4 and 14 March with locations identified based on model precursor sensitivity. Results are shown for surface values over the full model domain (including Mexico City and the surrounding rural area), excluding locations that showed little sensitivity response to either $\mathrm{NO}_{\mathrm{x}}$ or VOC. The sensitivity categorizations illustrate the shift from pri-
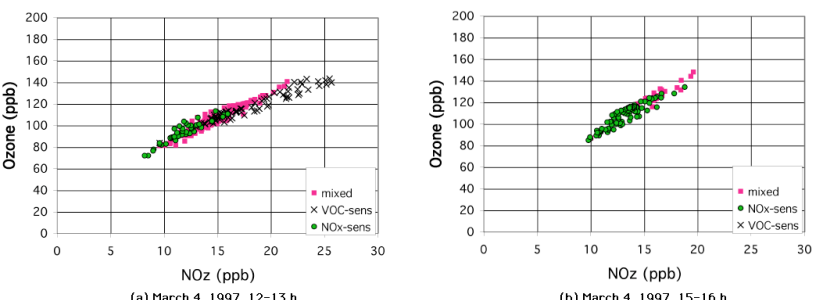

(a) March 4, 1997, 12-13
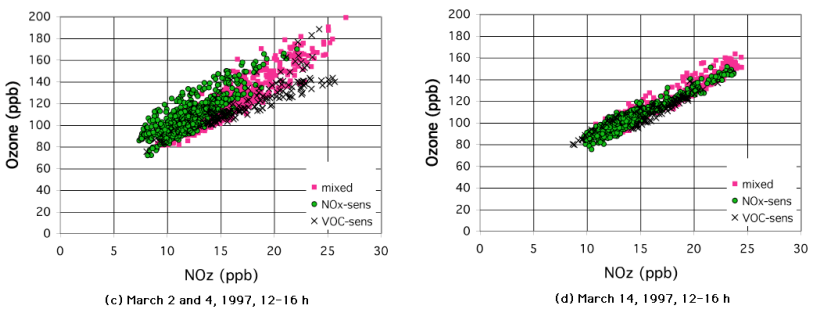

Fig. 4. $\mathrm{O}_{3}$ vs. $\mathrm{NO}_{\mathrm{Z}}(\mathrm{ppb})$ sorted by precursor sensitivity. Locations are identified as primarily sensitive to $\mathrm{NO}_{\mathrm{x}}$ (green circles), primarily sensitive to VOC (Xs), and with mixed sensitivity (pink squares). Results are for (a) 4 March, 12-13 h; (b) 4 March, 15$16 \mathrm{~h}$; (c) composite of 4 hourly intervals from $12 \mathrm{~h}$ to $16 \mathrm{~h}$ on 2 and $4 \mathrm{March}$; and (d) composite of 4 hourly intervals from $12 \mathrm{~h}$ to $16 \mathrm{~h}$ on 14 March, all in 1997.

marily VOC-sensitive conditions at $12-13 \mathrm{~h}$ on both days to primarily $\mathrm{NO}_{\mathrm{x}}$-sensitive conditions at $15-16 \mathrm{~h}$. The figure also shows a change in the values of ambient $\mathrm{O}_{3}$ versus $\mathrm{NO}_{\mathrm{y}}$ that apparently corresponds with the change in predicted sensitivity. VOC-sensitive conditions generally correspond with model $\mathrm{NO}_{\mathrm{y}}$ greater than $30 \mathrm{ppb}$ and $\mathrm{O}_{3} / \mathrm{NO}_{\mathrm{y}}$ ratios lower than 4.5. $\mathrm{NO}_{\mathrm{x}}$-sensitive conditions are associated with $\mathrm{NO}_{\mathrm{y}}$ below $25 \mathrm{ppb}$ and $\mathrm{O}_{3} / \mathrm{NO}_{\mathrm{y}}$ ratios higher than 4.5 (and usually higher than 6). Similarly, the model shows a shift in ambient $\mathrm{NO}_{\mathrm{y}}$ and $\mathrm{O}_{3} / \mathrm{NO}_{\mathrm{y}}$ between $12-13 \mathrm{~h}$ and $15-16 \mathrm{~h}$ that matches the predicted shift from VOC-sensitive to $\mathrm{NO}_{\mathrm{x}}$-sensitive conditions. The difference in ambient mixing ratios associated with $\mathrm{NO}_{\mathrm{x}}$-sensitive and $\mathrm{VOC}$-sensitive conditions is also illustrated by composite plots (Fig. 3g and h), which show $\mathrm{O}_{3}$ versus $\mathrm{NO}_{\mathrm{y}}$ for all four hour intervals from 12 to $16 \mathrm{~h}$ on the same plot. The composite plots show a clear separation between the values for predicted $\mathrm{O}_{3}$ and $\mathrm{NO}_{\mathrm{y}}$ associated with $\mathrm{NO}_{\mathrm{x}}$-sensitive and VOC-sensitive conditions on 2 March and 4 March. The separation between $\mathrm{NO}_{\mathrm{x}}$-sensitive and VOC-sensitive values is somewhat less on 14 March. There are also a few instances of VOC-sensitive conditions coincident with $\mathrm{O}_{3}$ and $\mathrm{NO}_{\mathrm{y}}$ that would suggest $\mathrm{NO}_{\mathrm{x}}$-sensitive conditions, and vice versus. These are most obvious in Fig. 3e. The link between $\mathrm{O}_{3} / \mathrm{NO}_{\mathrm{y}}$ and predicted ozone-precursor sensitivity is consistent with results from models in other locations described by Sillman and He (2002) and Sillman (1995).

Figure 4 shows model $\mathrm{O}_{3}$ versus $\mathrm{NO}_{z}$ associated with precursor sensitivity. In this and subsequent plots we show results at $12-13 \mathrm{~h}$ and $15-16 \mathrm{~h}$ only for $4 \mathrm{March}$, along with 

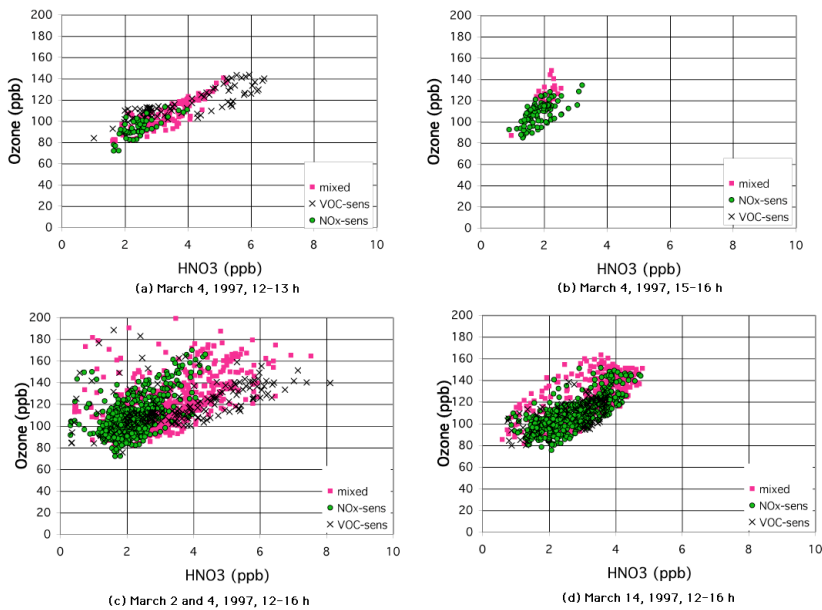

Fig. 5. $\mathrm{O}_{3}$ vs. $\mathrm{HNO}_{3}(\mathrm{ppb})$ sorted by precursor sensitivity, as in Fig. 4.

composite plots for $12-16 \mathrm{~h}$ for all three days. Here the difference between $\mathrm{NO}_{\mathrm{x}}$-sensitive and VOC-sensitive locations is relatively small. On 2 March and 4 March the $\mathrm{NO}_{\mathrm{x}}-$ sensitive locations (visible primarily at $15-16 \mathrm{~h}$ ) have $\mathrm{NO}_{\mathrm{z}}$ below $17 \mathrm{ppb}$ while the VOC-sensitive locations (at 12-13 h), with few exceptions, have $\mathrm{NO}_{\mathrm{z}}$ between 15 and $25 \mathrm{ppb}$. The correlation between $\mathrm{O}_{3}$ and $\mathrm{NO}_{\mathrm{z}}$ among $\mathrm{NO}_{\mathrm{x}}$-sensitive locations, if extended to higher $\mathrm{NO}_{\mathrm{z}}$, would show higher $\mathrm{O}_{3}$ relative to $\mathrm{NO}_{\mathrm{z}}$ in comparison with the VOC-sensitive locations. The VOC-sensitive locations mostly have $\mathrm{O}_{3} / \mathrm{NO}_{\mathrm{z}}$ ratios below 7, while the $\mathrm{NO}_{\mathrm{x}}$-sensitive locations had higher ratios. This difference between $\mathrm{NO}_{\mathrm{x}}$-sensitive and VOC-sensitive conditions is consistent with results from locations described by Sillman and $\mathrm{He}$ (2002) and Sillman et al. (2003). However on 14 March the $\mathrm{O}_{3}-\mathrm{NO}_{z}$ correlation is nearly identical for both $\mathrm{NO}_{\mathrm{x}}$-sensitive and VOC-sensitive conditions, and corresponds with the correlation associated solely with VOCsensitive conditions on the other days.

Even on 2 March and 4 March the difference in $\mathrm{O}_{3} / \mathrm{NO}_{\mathrm{Z}}$ between $\mathrm{NO}_{\mathrm{x}}$-sensitive and VOC-sensitive locations in the model for Mexico is smaller than in models for other locations. There is also significant overlap between $\mathrm{O}_{3}-\mathrm{NO}_{z}$ correlations associated between $\mathrm{NO}_{\mathrm{x}}$-sensitive and VOCsensitive conditions, so that it may not be possible to clearly distinguish between $\mathrm{NO}_{\mathrm{x}}$-sensitive and VOC-sensitive correlation patterns. The difference between $\mathrm{NO}_{\mathrm{x}}$-sensitive and VOC-sensitive conditions corresponds to a difference in $\mathrm{NO}_{\mathrm{z}}$ of less than $30 \%$. This is comparable to the $20 \%$ uncertainty in model ambient concentrations attributed to uncertainties in chemical reaction rates (Gao et al., 1996). The $\mathrm{O}_{3}-\mathrm{NO}_{\mathrm{Z}}$ slope shown in Fig. 4 (for 4 March) was significantly lower at $12-13 \mathrm{~h}$ and higher at $15-16 \mathrm{~h}$ (4 vs. 6), but the difference in slope was not consistent among the three model days. The slope for 2 March was similar at 12-13 h and 15-16 h (6).
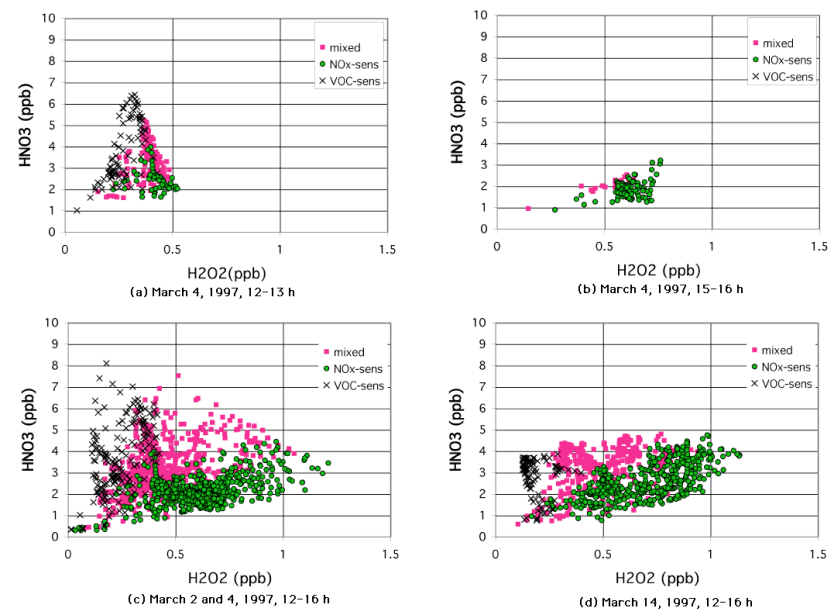

Fig. 6. $\mathrm{H}_{2} \mathrm{O}_{2}$ vs. $\mathrm{HNO}_{3}$ (ppb) sorted by precursor sensitivity, as in Fig. 4.

Results for $\mathrm{O}_{3}$ versus $\mathrm{HNO}_{3}$ (Fig. 5) also show a difference between $\mathrm{NO}_{\mathrm{x}}$-sensitive and VOC-sensitive locations on 2 March and 4 March, and a corresponding shift in values between $12-13 \mathrm{~h}$ and $15-16 \mathrm{~h}$. The VOC-sensitive locations mostly have $\mathrm{HNO}_{3}$ (interpreted to represent the sum of gas-phase $\mathrm{HNO}_{3}$ and particulate $\mathrm{NO}_{3}$ ) greater than $3.5 \mathrm{ppb}$ and $\mathrm{O}_{3} / \mathrm{HNO}_{3}$ below 30. The $\mathrm{NO}_{\mathrm{x}}$-sensitive locations have $\mathrm{HNO}_{3}$ below $3.2 \mathrm{ppb}$ and $\mathrm{O}_{3} / \mathrm{HNO}_{3}$ above 40 . However, these results differ from results in other locations. Sillman (1995) and Sillman and He (2002) found that VOCsensitive conditions usually corresponded to $\mathrm{O}_{3} / \mathrm{HNO}_{3}$ below 15 and that $\mathrm{NO}_{\mathrm{x}}$-sensitive conditions usually corresponded to $\mathrm{O}_{3} / \mathrm{HNO}_{3}$ between 20 and 30 (assuming $\mathrm{O}_{3}$ above $100 \mathrm{ppb}$ ). Much of the $\mathrm{O}_{3}$ and $\mathrm{HNO}_{3}$ associated with $\mathrm{NO}_{\mathrm{x}}$-sensitive conditions in Sillman and He (2002) would be associated with VOC-sensitive conditions in the model for Mexico City shown here. There is also much greater overlap between the values associated with VOC-sensitive conditions and with $\mathrm{NO}_{\mathrm{x}}$-sensitive conditions in the model for Mexico City. Some VOC-sensitive locations have low $\mathrm{HNO}_{3}$ and high $\mathrm{O}_{3} / \mathrm{HNO}_{3}$, equivalent to the $\mathrm{NO}_{\mathrm{x}}$-sensitive locations. On 14 March there is again no difference between the values of $\mathrm{O}_{3}$ and $\mathrm{HNO}_{3}$ associated with $\mathrm{NO}_{\mathrm{x}}$-sensitive and VOC-sensitive conditions, in contrast with results on 2 March and 4 March and in contrast with previous results from other cities.

$\mathrm{O}_{3}$ versus PAN (not shown) shows no discernible difference between $\mathrm{NO}_{\mathrm{x}}$-sensitive and VOC-sensitive locations. This result was also reported by Sillman et al. (2003) for Paris.

Results for $\mathrm{H}_{2} \mathrm{O}_{2}$ versus $\mathrm{HNO}_{3}$ (Fig. 6) show a large difference between $\mathrm{NO}_{\mathrm{x}}$-sensitive and VOC-sensitive locations and an equivalent shift in values between $12-13 \mathrm{~h}$ (VOCsensitive) and $15-16 \mathrm{~h}\left(\mathrm{NO}_{\mathrm{x}}\right.$-sensitive). VOC-sensitive locations mostly have low $\mathrm{H}_{2} \mathrm{O}_{2} \quad(<0.5 \mathrm{ppb})$ and low 

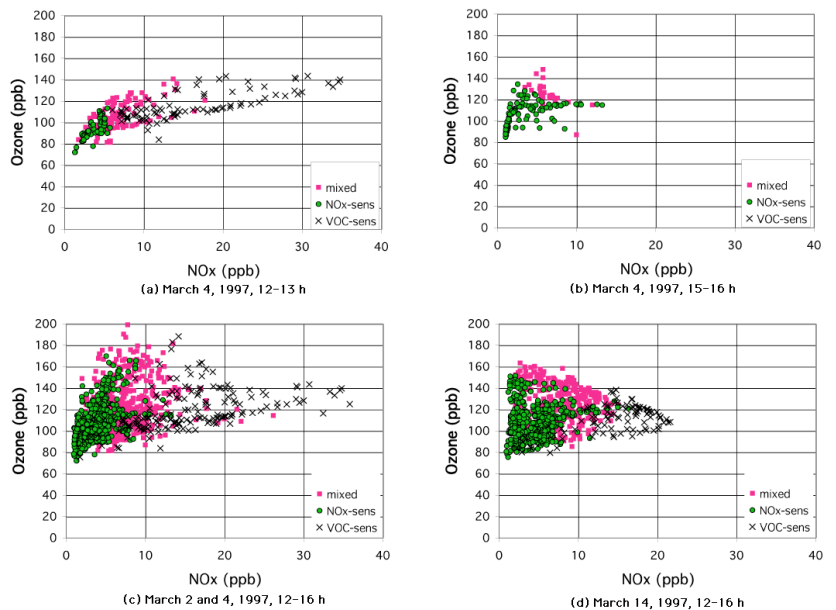

Fig. 7. $\mathrm{O}_{3}$ vs. $\mathrm{NO}_{\mathrm{x}}(\mathrm{ppb})$ sorted by precursor sensitivity, as in Fig. 4.

$\mathrm{H}_{2} \mathrm{O}_{2} / \mathrm{HNO}_{3}$ ratios $(<0.1)$. $\mathrm{NO}_{\mathrm{x}}$-sensitive locations have higher $\mathrm{H}_{2} \mathrm{O}_{2}(0.2-1 \mathrm{ppb})$ and $\mathrm{H}_{2} \mathrm{O}_{2} / \mathrm{HNO}_{3}(>0.2)$. This difference between $\mathrm{NO}_{\mathrm{x}}$-sensitive and VOC-sensitive locations is similar on all three model days, including 14 March. As in previous studies (Sillman and $\mathrm{He}, 2002$ ), there is little correlation between $\mathrm{H}_{2} \mathrm{O}_{2}$ and $\mathrm{HNO}_{3}$ except possibly in subregions with either uniformly $\mathrm{NO}_{\mathrm{x}}$-sensitive or uniformly VOC-sensitive conditions. However there is a large difference in $\mathrm{H}_{2} \mathrm{O}_{2} / \mathrm{HNO}_{3}$ values associated with $\mathrm{NO}_{\mathrm{x}}$-sensitive and VOC-sensitive chemistry.

Model $\mathrm{H}_{2} \mathrm{O}_{2}$ and $\mathrm{HNO}_{3}$ are both much lower than the model values in Sillman and $\mathrm{He}$ (2002) but the $\mathrm{H}_{2} \mathrm{O}_{2} / \mathrm{HNO}_{3}$ ratios associated with $\mathrm{NO}_{\mathrm{x}}$-sensitive and $\mathrm{VOC}$-sensitive conditions are similar to the values reported by Sillman and He. The low $\mathrm{H}_{2} \mathrm{O}_{2}$ may be due in part to the model boundary conditions (with zero $\mathrm{H}_{2} \mathrm{O}_{2}$ ), although we do not anticipate elevated $\mathrm{H}_{2} \mathrm{O}_{2}$ upwind from Mexico City. It is noteworthy that the model predicts $\mathrm{NO}_{\mathrm{x}}$-sensitive conditions even for low $\mathrm{H}_{2} \mathrm{O}_{2}$. Low ambient $\mathrm{H}_{2} \mathrm{O}_{2}$ is often interpreted as evidence for VOC-sensitive conditions (e.g. Nunnermacker et al., 2008). Here, relatively low $\mathrm{H}_{2} \mathrm{O}_{2}$ can coincide with $\mathrm{NO}_{\mathrm{x}}-$ sensitive conditions because $\mathrm{HNO}_{3}$ is also very low.

Lastly, results for $\mathrm{O}_{3}$ versus $\mathrm{NO}_{x}$ (Fig. 7) show a significant difference between $\mathrm{NO}_{\mathrm{x}}$-sensitive and $\mathrm{VOC}$-sensitive locations on all three days. VOC-sensitive locations were associated with $\mathrm{NO}_{\mathrm{x}}$ above $10 \mathrm{ppb}$, while $\mathrm{NO}_{\mathrm{x}}$-sensitive locations were associated with lower values. $\mathrm{O}_{3}$ versus $\mathrm{NO}_{\mathrm{x}}$ was proposed by McKeen et al. (1991) as a way to distinguish between $\mathrm{NO}_{\mathrm{x}}$-sensitive and VOC-sensitive locations. It was omitted by Sillman and $\mathrm{He}$ (2002) because they found many exceptional situations in which high $\mathrm{NO}_{\mathrm{x}}$ corresponded with $\mathrm{NO}_{\mathrm{x}}$-sensitive conditions and lower $\mathrm{NO}_{\mathrm{x}}$ with VOC-sensitive conditions. We did not find similar exceptions in Mexico City.

Ozone-precursor sensitivity in the model for Mexico City is also strongly correlated with the $\mathrm{NO}_{\mathrm{x}} / \mathrm{NO}_{\mathrm{y}}$ ratio (Fig. 8)
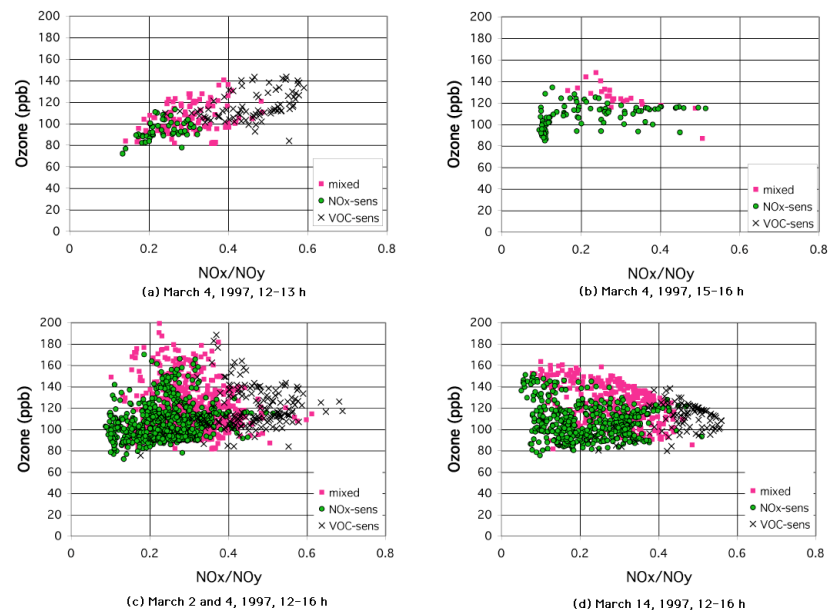

Fig. 8. $\mathrm{O}_{3}$ vs. $\mathrm{NO}_{\mathrm{x}} / \mathrm{NO}_{\mathrm{y}}(\mathrm{ppb})$ sorted by precursor sensitivity, as in Fig. 4.

that is widely used to represent photochemical aging (e.g. Olszyna et al., 1994). VOC-sensitive locations have $\mathrm{NO}_{\mathrm{x}} / \mathrm{NO}_{\mathrm{y}}$ greater than 0.4 , while $\mathrm{NO}_{\mathrm{x}}$-sensitive locations have lower $\mathrm{NO}_{\mathrm{x}} / \mathrm{NO}_{\mathrm{y}}$. This result also may not be applicable to other locations, but it may be useful in evaluating model ozoneprecursor predictions for Mexico.

\section{Discussion}

The model results for Mexico show two distinct features in comparison with other regions: a relatively high amount of organic nitrates (especially PAN) and low $\mathrm{HNO}_{3}$; and differences in the correlation between ozone-precursor sensitivity and model values for secondary species. The model predicts that VOC-sensitive chemistry is associated with high $\mathrm{NO}_{\mathrm{y}}$ and with low $\mathrm{O}_{3} / \mathrm{NO}_{\mathrm{y}}$ and $\mathrm{H}_{2} \mathrm{O}_{2} / \mathrm{HNO}_{3}$, in agreement with previous results. In contrast with some previous results, however, ozone-precursor sensitivity was also strongly correlated with the ratios $\mathrm{O}_{3} / \mathrm{NO}_{\mathrm{x}}$ and $\mathrm{NO}_{\mathrm{x}} / \mathrm{NO}_{\mathrm{y}}$ and was weakly correlated with $\mathrm{O}_{3} / \mathrm{NO}_{\mathrm{Z}}$ and $\mathrm{O}_{3} / \mathrm{HNO}_{3}$. The results also have some implications for $\mathrm{O}_{3}-\mathrm{NO}_{\mathrm{x}}-\mathrm{VOC}$ sensitivity in Mexico, especially when considered in comparison with results from other investigations.

\subsection{PAN and $\mathrm{HNO}_{3}$}

The predicted ratio of PAN to $\mathrm{O}_{3}$ is comparable to the predicted ratio in Paris and is higher than the ratio in Nashville by a factor of two. This result can be analyzed in relation to the PAN steady state Eq. (1). Two factors might contribute to a higher PAN/ $\mathrm{O}_{3}$ ratio: a larger rate of production due to Reaction (R5) $\left(\mathrm{OH}+\mathrm{CH}_{3} \mathrm{CHO}\right)$ and equivalent reactions for other PAN sources; or a slower rate of decomposition for PAN (R6) due to lower temperatures. 
The rate of Reaction (R5) is broadly representative of all $\mathrm{VOC}+\mathrm{OH}$ reactions and is likely to vary in proportion to the rate of production of $\mathrm{O}_{3}$. A significant increase in the $\mathrm{PAN} / \mathrm{O}_{3}$ ratio would be possible if the rate of production of $\mathrm{O}_{3}$ during the events in Mexico and in Paris was larger than the rate of production in Nashville, despite similar $\mathrm{O}_{3}$ concentrations. This would occur if the Nashville model represented downwind conditions with transported $\mathrm{O}_{3}$. The Nashville event was associated with a multi-day regional pollution episode with up to $85 \mathrm{ppbO}_{3}$ in rural upwind locations, so it is expected that rates of ozone production would be lower in Nashville than in Mexico for a given $\mathrm{O}_{3}$ concentration.

Another possibility is that the speciated VOC in Mexico and in Paris contained a higher proportion of specific precursors of PAN than the VOC in Nashville. This is a likely possibility for Mexico because subsequent measurements showed large decreases in both PAN and the $\mathrm{PAN} / \mathrm{O}_{3}$ ratio, as a result of large reductions in emission of light olefins (Marley et al., 2007).

While these are possibilities, the differences in PAN and PAN $/ \mathrm{O}_{3}$ can also be explained by the influence of temperature on the PAN decomposition rate. Maximum surface temperature during the model events was much warmer in Nashville (307 K) than in Paris (300) or in Mexico (300). Based on current rate estimates (Sander et al., 2003) the PAN decomposition rate in Nashville should be higher than the rate in Paris or in Mexico by a factor of three. These large rate differences may be partially compensated by differences in the height of the convective mixed layer. The estimated mixed layer height was higher in Nashville $(2600 \mathrm{~m})$ than in Paris $(2000 \mathrm{~m})$ but comparable to the mixing heights for Mexico (2700-3200 m on 2 and 4 March, 1900-2600 on 14 March, from West et al., 2004). The PAN lifetime (40 min at $298 \mathrm{~K}, 10 \mathrm{~min}$ at $307 \mathrm{~K}$ ) is somewhat shorter than the time scale for mixing in an active convective boundary layer, so that the effective removal rate for PAN is also influenced by the temperature throughout the mixed layer. If the PAN decomposition rate is based on the estimated average temperature within the convective mixed layer, the rate is still faster in Nashville than in Paris by approximately a factor of two. Due to the deeper convective mixed layer in Mexico, the effective PAN decomposition rate in Mexico should be slower than in Paris, and should be slower than in Nashville by at least a factor of three. Therefore, the difference in the PAN decomposition rate is sufficient to explain the difference in $\mathrm{PAN} / \mathrm{O}_{3}$ by itself.

The PAN/HNO $\mathrm{H}_{3}$ ratio also shows large differences between Mexico and the other locations. The PAN/HNO 3 increases from 0.4 (Nashville) to 1 (Paris) to 3 or higher in Mexico. This difference in $\mathrm{PAN} / \mathrm{HNO}_{3}$ between Nashville and Paris is comparable to the difference in $\mathrm{PAN} / \mathrm{O}_{3}$ between the two locations, and can also be explained by the difference in the PAN decomposition rate associated with temperature. However, the difference between Mexico and the other cities is much larger for $\mathrm{PAN} / \mathrm{HNO}_{3}$ than for $\mathrm{PAN} / \mathrm{O}_{3}$, and cannot be explained solely in terms of temperature. The formation of $\mathrm{PAN}$ and $\mathrm{HNO}_{3}$ is driven by Reactions (R5) $\left(\mathrm{OH}+\mathrm{CH}_{3} \mathrm{CHO}\right)$ and $(\mathrm{R} 2)\left(\mathrm{OH}+\mathrm{NO}_{2}\right)$ respectively. The higher $\mathrm{PAN} / \mathrm{HNO}_{3}$ in Mexico suggests a higher ratio of $\mathrm{CH}_{3} \mathrm{CHO}$ (or of other organic precursors of PAN) to $\mathrm{NO}_{2}$ or, more generally, a higher ratio of reactivity-weighted VOC to $\mathrm{NO}_{\mathrm{x}}$. The high $\mathrm{VOC} / \mathrm{NO}_{\mathrm{x}}$ ratio in Mexico was included in the model emissions, and recent measurements have found that the ratio of reactivity-weighted VOC to $\mathrm{NO}_{\mathrm{x}}$ in Mexico is higher than in New York City by a factor of ten (Shirley et al., 2006).

The high $\mathrm{PAN} / \mathrm{HNO}_{3}$ ratio also has implications for the behavior of odd hydrogen radicals $\left(\mathrm{OH}\right.$ and $\left.\mathrm{HO}_{2}\right)$ in Mexico City. Normally the formation of peroxides and $\mathrm{HNO}_{3}$ represent the main radical sinks. Here, the net formation of PAN and other organic nitrates is much larger than the formation rates for both peroxides and $\mathrm{HNO}_{3}$. This may pose a problem for the constrained steady state (CSS) evaluations of measured $\mathrm{OH}$ and $\mathrm{HO}_{2}$ (e.g. Shirley et al., 2006; Volkamer et al., 2007). The CSS calculations determine the expected $\mathrm{OH}$ and $\mathrm{HO}_{2}$ based on measured concentrations of long-lived species ( $\mathrm{NO}, \mathrm{NO}_{2}, \mathrm{O}_{3}$, speciated VOC). It is difficult to include net formation of PAN in this representation because the measurements may not include the direct precursors of PAN (acetaldehyde and methyl glyoxal). Shirley et al. (2006) found good agreement between calculated and measured $\mathrm{OH}$ and $\mathrm{HO}_{2}$ despite their apparent omission of PAN as a radical sink, but the role of PAN may represent a significant uncertainty.

\subsection{Indicators for $\mathrm{NO}_{\mathrm{x}}-\mathrm{VOC}$ sensitivity}

Results from the Mexico City simulations show significant differences from previous results (Sillman, 1995; Sillman and $\mathrm{He}, 2002$ ) in the use of ratios such as $\mathrm{O}_{3} / \mathrm{NO}_{\mathrm{z}}, \mathrm{O}_{3} / \mathrm{HNO}_{3}$ and $\mathrm{H}_{2} \mathrm{O}_{2} / \mathrm{HNO}_{3}$ as measurement-based "indicators" of $\mathrm{O}_{3}$ $\mathrm{NO}_{\mathrm{x}}$-VOC sensitivity. The differences are especially important because these types of ratios and correlations provide useful evidence on $\mathrm{NO}_{\mathrm{x}}$-VOC sensitivity only if they behave consistently in models for a wide range of conditions. If a particular ratio appears to be correlated with $\mathrm{NO}_{\mathrm{x}}$-VOC sensitivity only for certain model conditions, then it is unclear whether the correlation reflects the underlying photochemical process or whether it is accidental.

Here we have found that $\mathrm{H}_{2} \mathrm{O}_{2} / \mathrm{HNO}_{3}$ in the model for Mexico correlates with model $\mathrm{NO}_{\mathrm{x}}$-VOC sensitivity consistently with results from other cities. The $\mathrm{H}_{2} \mathrm{O}_{2} / \mathrm{HNO}_{3}$ ratio is also related more closely to $\mathrm{NO}_{\mathrm{x}}$-VOC chemistry than the other ratios. $\mathrm{O}_{3} / \mathrm{NO}_{\mathrm{y}}$ also correlates with model $\mathrm{NO}_{\mathrm{x}}-\mathrm{VOC}$ sensitivity in the same way as in the previous studies, but the behavior of individual $\mathrm{NO}_{\mathrm{y}}$ species is somewhat different. The ratio $\mathrm{O}_{3} / \mathrm{NO}_{\mathrm{x}}$ is strongly correlated with $\mathrm{NO}_{\mathrm{x}}-\mathrm{VOC}$ sensitivity in Mexico and this accounts for most of the correlation between $\mathrm{O}_{3} / \mathrm{NO}_{\mathrm{y}}$ and $\mathrm{NO}_{\mathrm{x}}-\mathrm{VOC}$ sensitivity. In the 
previous results from Sillman and $\mathrm{He}$ (2002) high $\mathrm{O}_{3} / \mathrm{NO}_{\mathrm{x}}$ tended to correlate with $\mathrm{NO}_{\mathrm{x}}$-sensitive conditions, but there were significant exceptions in which high $\mathrm{O}_{3} / \mathrm{NO}_{\mathrm{x}}$ coincided with VOC-sensitive chemistry.

The major difference from previous results involves $\mathrm{O}_{3} / \mathrm{NO}_{\mathrm{z}}$ and $\mathrm{O}_{3} / \mathrm{HNO}_{3}$. Both of these ratios show a small difference between $\mathrm{NO}_{\mathrm{x}}$-sensitive and VOC-sensitive conditions on two of the three model days, and no difference on the third day (14 March). The poor results for these ratios may be due in part to the much higher net production of PAN and other organic nitrates in Mexico as opposed to other locations. The ratio $\mathrm{O}_{3} / \mathrm{PAN}$ is usually not correlated at all with $\mathrm{NO}_{\mathrm{x}}$-VOC-sensitivity (Sillman et al., 2003), so that if $\mathrm{NO}_{\mathrm{z}}$ consists mainly of organic nitrates the correlation between $\mathrm{O}_{3} / \mathrm{NO}_{\mathrm{z}}$ and $\mathrm{NO}_{\mathrm{x}}-\mathrm{VOC}$-sensitivity should be weaker. In this context it is noteworthy that the 14 March event had somewhat lower afternoon temperatures than the other days $\left(24^{\circ} \mathrm{C}\right.$ vs. $27^{\circ} \mathrm{C}$ ), which leads to higher concentrations of PAN.

In addition to showing a weaker correlation with $\mathrm{NO}_{\mathrm{x}}$ VOC-sensitivity, the ratio $\mathrm{O}_{3} / \mathrm{HNO}_{3}$ also showed a shift towards higher values for both $\mathrm{NO}_{\mathrm{x}}$-sensitive and VOCsensitive conditions in the model for Mexico relative to models for other locations. Elsewhere it was found that $\mathrm{NO}_{\mathrm{x}}-$ sensitive chemistry was associated with $\mathrm{O}_{3} / \mathrm{HNO}_{3}$ greater than 15, but in the model for Mexico VOC-sensitive chemistry is associated with $\mathrm{O}_{3} / \mathrm{HNO}_{3}$ as high as 30 . This shift may also be due to the high rate of formation of organic nitrates and the high $\mathrm{PAN} / \mathrm{HNO}_{3}$.

The rationale for $\mathrm{O}_{3} / \mathrm{HNO}_{3}$ as a $\mathrm{NO}_{\mathrm{x}}-\mathrm{VOC}$ sensitivity indicator is based on the radical chemistry summarized in Sect. 2. $\mathrm{NO}_{\mathrm{x}}$-sensitive chemistry occurs when the formation rate of peroxides ( $\mathrm{R} 1 \mathrm{a}$ and $\mathrm{R} 1 \mathrm{~b}$ ) is high relative to the formation rate of nitric acid (R2) and VOC-sensitive chemistry occurs when the formation rate of $\mathrm{HNO}_{3}$ is larger by more than a factor of 2. The larger formation rate of $\mathrm{HNO}_{3}$ as a fraction of the total radical source leads to lower $\mathrm{O}_{3} / \mathrm{HNO}_{3}$ and $\mathrm{O}_{3} / \mathrm{NO}_{\mathrm{Z}}$ in VOC-sensitive locations. In Mexico, however, the radical sink is dominated by formation of PAN and other organic nitrates. Formation of $\mathrm{HNO}_{3}$ is smaller as a fraction of the total radical sink even when it is large relative to formation of peroxides. Consequently the $\mathrm{O}_{3} / \mathrm{HNO}_{3}$ associated with $\mathrm{NO}_{\mathrm{x}}$-sensitive and VOC-sensitive conditions in Mexico are both larger than the values associated with $\mathrm{NO}_{\mathrm{x}}-$ sensitive and VOC-sensitive conditions in other locations.

Sillman (1995) noted that the accumulated sink for odd hydrogen radicals may be represented by the sum $2 \mathrm{H}_{2} \mathrm{O}_{2}+\mathrm{NO}_{\mathrm{Z}}$ and that the ratio $\mathrm{O}_{3} /\left(2 \mathrm{H}_{2} \mathrm{O}_{2}+\mathrm{NO}_{\mathrm{z}}\right)$ remains invariant in polluted regions for both $\mathrm{NO}_{\mathrm{x}}$-sensitive and VOC-sensitive conditions. Since $\mathrm{NO}_{\mathrm{x}}$-sensitive chemistry occurs when formation of peroxides is high relative to formation of $\mathrm{HNO}_{3}$, $\mathrm{NO}_{\mathrm{x}}$-sensitive chemistry should in theory be associated with high values of the ratio $\mathrm{O}_{3} /\left(\mathrm{HNO}_{3}+\mathrm{NO}_{\mathrm{Z}}\right)$. $\mathrm{NO}_{\mathrm{x}}$-sensitive and VOC-sensitive regions coincide with high $(>6)$ and low $(<5)$ values for $\mathrm{O}_{3} /\left(\mathrm{HNO}_{3}+\mathrm{NO}_{\mathrm{Z}}\right)$ in both the model for Mexico and the models for Nashville, Paris and elsewhere reported by Sillman and He (2002). Since Mexico has much lower $\mathrm{HNO}_{3} / \mathrm{NO}_{\mathrm{z}}$ than other locations, the corresponding values for $\mathrm{O}_{3} / \mathrm{HNO}_{3}$ associated with both $\mathrm{NO}_{\mathrm{x}}$-sensitive and VOCsensitive locations are higher than elsewhere.

Though not shown here, the high $\mathrm{PAN} / \mathrm{HNO}_{3}$ may also affect the $\mathrm{L}_{\mathrm{n}} / \mathrm{Q}$ approach developed by Kleinman et al. (1997, $2005)$ to evaluate how instantaneous production of $\mathrm{O}_{3}$ varies with $\mathrm{NO}_{\mathrm{x}}$ and VOC. The $\mathrm{L}_{\mathrm{n}} / \mathrm{Q}$ is based on the rate of removal of $\mathrm{NO}_{\mathrm{x}}\left(\mathrm{L}_{\mathrm{n}}\right)$, and the relative rate of production of odd hydrogen radicals $(\mathrm{Q})$, assuming that formation of $\mathrm{HNO}_{3}$ is the dominant radical sink. An $\mathrm{L}_{\mathrm{n}} / \mathrm{Q}$ greater than 0.5 identifies a situation in which formation of $\mathrm{HNO}_{3}$ is greater than formation of peroxides and indicates local VOC-sensitive chemistry. A modification may be necessary for cases in which formation of organic nitrates represents the dominant radical sink.

A change in rate of PAN formation should not affect the relative sensitivity of $\mathrm{O}_{3}$ to $\mathrm{NO}_{\mathrm{x}}$ and VOC directly because PAN formation represents a sink for both $\mathrm{NO}_{\mathrm{x}}$ and radicals. However, a change in PAN formation can affect the interpretation of measurements that are associated with $\mathrm{NO}_{\mathrm{x}}-$ sensitive and VOC-sensitive conditions, including $\mathrm{O}_{3} / \mathrm{NO}_{\mathrm{z}}$, $\mathrm{NO}_{\mathrm{x}} / \mathrm{NO}_{\mathrm{y}}$ and $\mathrm{L}_{\mathrm{n}} / \mathrm{Q}$.

\subsection{Implications for ozone-precursor sensitivity}

Model-based predictions for the response of $\mathrm{O}_{3}$ to reduced $\mathrm{NO}_{\mathrm{x}}$ and VOC in urban areas are always subject to significant uncertainty. The uncertainties are especially important in this case because emission of VOC have been increased by a factor of three relative to the original inventory. The increased emission rates have been justified based on ambient measurements (Arriaga-Colina et al., 2004; West et al., 2004) but the process implies significant uncertainty, both for VOC by itself and for VOC relative to $\mathrm{NO}_{\mathrm{x}}$. Model predictions for $\mathrm{O}_{3}-\mathrm{NO}_{\mathrm{x}}-\mathrm{VOC}$ sensitivity are sensitive to emission rates for total VOC and also to VOC speciation. There are also uncertainties related to various model dynamical and photochemical properties (e.g. Thornton et al., 2002). O3-precursor sensitivity also can vary from day to day, and the three events described here may not be representative.

Results from this model suggest mixed sensitivity to $\mathrm{NO}_{\mathrm{x}}$ and VOC, rather than a purely $\mathrm{NO}_{\mathrm{x}}$-sensitive or VOCsensitive environment. Results also suggest a shift from a primarily VOC-sensitive environment before $14 \mathrm{~h}$ to a more $\mathrm{NO}_{\mathrm{x}}$-sensitive environment after $16 \mathrm{~h}$. The instantaneous production rates for $\mathrm{O}_{3}$ in the model (as opposed to the $\mathrm{O}_{3}$ concentrations) shift from being primarily VOC-sensitive in the morning to primarily $\mathrm{NO}_{\mathrm{x}}$-sensitive after noon. This prediction might be tested though evaluation of instantaneous production rates based on measured $\mathrm{NO}$ and $\mathrm{HO}_{2}$ (as in Shirley et al., 2006). A shift from VOC-sensitive conditions during the morning hours to $\mathrm{NO}_{\mathrm{x}}$-sensitive conditions during the afternoon has been found previously in many locations (e.g. Milford et al., 1994, Kleinman et al., 2005) and may be 
due to photochemical aging or to increased vertical dilution. Lei et al. (2008) also reported a shift towards $\mathrm{NO}_{\mathrm{x}}$-sensitive conditions associated with photochemical aging in the plume downwind from Mexico City.

The sensitivity results described here contrast sharply with the findings of Lei et al. (2007, 2008). Lei et al. (2007) applied a photochemical model to a different episode (1316 April 2003) and concluded that $\mathrm{O}_{3}$ remains predominantly sensitive to VOC throughout the day. The sensitivity predictions from Lei et al. (2007) are also consistent with results from Stephens et al. (2008) based on the contrast between weekday and weekend $\mathrm{O}_{3}$.

The most likely reason for the difference in sensitivity predictions between West et al. (2004) and Lei et al. (2007) is the decrease in VOC emission rates and $\mathrm{VOC} / \mathrm{NO}_{\mathrm{x}}$ emission ratios between 1997 and 2003. Results from Zavala et al. (2009) suggest that CO and VOC emissions from mobile sources decreased by approximately $40 \%$ over this time period while $\mathrm{NO}_{\mathrm{x}}$ emissions remained unchanged. Marley et al. (2007) also reported evidence of a significant decrease in emissions of light olefins based on changes in ambient PAN concentrations. Other possible reasons for the difference include different estimations of VOC emissions and different meteorological conditions during the simulated events. It has also been suggested that vertical mixing is too rapid in the CIT model used here (Velasco et al., 2007), which can also lead to a more $\mathrm{NO}_{\mathrm{x}}$-sensitive simulation, but West et al. (2004) report good agreement with $\mathrm{NO}_{\mathrm{y}}$ measurements, suggesting that errors in vertical mixing may not be large.

West et al. (2004) and Lei et al. (2007) both increased VOC emissions with respect to their base inventories, but Lei et al. increased emissions by $65 \%$ whereas West et al. increased emissions by $200 \%$. The resulting VOC emissions were 1425 kton per year in West et al. and 900 kton per year in Lei et al. The lower VOC emissions in Lei et al. result in a more VOC-sensitive model. The adjustment by Lei et al. also varied for individual VOCs, including a factor-of9 increase for HCHO and no increase for alkenes. The resulting VOC speciation differed from West et al. West et al. and Lei et al. both evaluated their model results using measured $\mathrm{O}_{3}$, VOC and $\mathrm{NO}_{\mathrm{y}}$ and both interpreted the available $\mathrm{NO}_{\mathrm{x}}$ measurements as representing $\mathrm{NO}_{\mathrm{y}}$. The smaller emissions adjustment used by Lei et al. were also supported by measurement-based analyses, although with some uncertainty (Velasco et al., 2005, 2007). It is also possible that the different emissions adjustments used by West et al. and Lei et al. reflect reductions in ambient VOC between 1997 and 2003. Accuracy of the emission inventory (including both total VOC, $\mathrm{VOC} / \mathrm{NO}_{\mathrm{x}}$ ratios and VOC speciation) has historically had a large impact on model predictions for ozoneprecursor sensitivity (e.g. Pierce et al., 1998).

The difference between the models is also closely associated with differences in ambient $\mathrm{NO}_{\mathrm{x}}$ and $\mathrm{NO}_{\mathrm{y}}$ in the models. The results here show that VOC-sensitive conditions in the model by West et al. are associated with model ambient $\mathrm{NO}_{\mathrm{x}}$ above $10 \mathrm{ppb}$ and $\mathrm{NO}_{\mathrm{y}}$ above $30 \mathrm{ppb}$, while $\mathrm{NO}_{\mathrm{x}}$-sensitive conditions are associated with lower $\mathrm{NO}_{\mathrm{x}}$ and $\mathrm{NO}_{\mathrm{y}}$. Median $\mathrm{NO}_{\mathrm{x}}$ during the afternoon is below $10 \mathrm{ppb}$. By contrast, in the model by Lei et al., $\mathrm{NO}_{\mathrm{x}}$ varies from 10 to $80 \mathrm{ppb}$ between $12 \mathrm{~h}$ and $17 \mathrm{~h}$ and is rarely below $10 \mathrm{ppb}$. The high $\mathrm{NO}_{\mathrm{x}}$ values in the model by Lei et al. correspond with VOCsensitive conditions in the model by West et al., and the $\mathrm{NO}_{\mathrm{x}}$-sensitive conditions in the model by West et al. correspond to lower ambient $\mathrm{NO}_{\mathrm{x}}$ than is found in the model by Lei et al. $\mathrm{NO}_{\mathrm{x}} / \mathrm{NO}_{\mathrm{y}}$ ratios were also much higher in Lei et al. (2007). The VOC-sensitive response in Lei et al. was associated with $\mathrm{NO}_{\mathrm{z}} / \mathrm{NO}_{\mathrm{y}}$ equal to 0.7 or lower (equivalent to $\mathrm{NO}_{\mathrm{x}} / \mathrm{NO}_{\mathrm{y}}$ equal to 0.3 or higher), and the region with low $\mathrm{NO}_{\mathrm{x}} / \mathrm{NO}_{\mathrm{y}}$ coincides with high $\mathrm{O}_{3}$. In the model by West et al. high $\mathrm{O}_{3}$ coincided with $\mathrm{NO}_{\mathrm{x}} / \mathrm{NO}_{\mathrm{y}}$ from 0.2 to 0.6 and the lower values $\left(\mathrm{NO}_{\mathrm{x}} / \mathrm{NO}_{\mathrm{y}}<0.4\right)$ had $\mathrm{NO}_{\mathrm{x}}$-sensitive chemistry. In addition to having lower $\mathrm{NO}_{\mathrm{x}} / \mathrm{NO}_{\mathrm{y}}$, the model by West et al. predicted $\mathrm{NO}_{\mathrm{x}}$-sensitive chemistry for somewhat higher $\mathrm{NO}_{\mathrm{x}} / \mathrm{NO}_{\mathrm{y}}$ than was reported by Lei et al. $(2007,2008)$.

This difference in ambient $\mathrm{NO}_{\mathrm{x}}$ could be caused by differences in meteorology or by differences in $\mathrm{NO}_{\mathrm{x}}$ emission rates. The episode investigated by Lei et al. (15 April 2003) had unusually stagnant conditions, which leads to higher $\mathrm{NO}_{\mathrm{x}}$ and $\mathrm{NO}_{\mathrm{y}}$ and also makes VOC-sensitive chemistry more likely (Milford et al., 1994). The difference in $\mathrm{NO}_{\mathrm{x}}$ could also be caused by differences in VOC emission rates and speciation, since formation of organic nitrates appears to be the dominant removal process for $\mathrm{NO}_{\mathrm{x}}$.

The difference between the sensitivity predictions from the models by West et al. and Lei et al. might be resolved by careful measurement of $\mathrm{NO}_{\mathrm{x}}$ and $\mathrm{NO}_{\mathrm{y}}$. In this context it is noteworthy that Shirley et al. (2006) measured $\mathrm{NO}_{\mathrm{x}}$ at a site in Mexico City during 2003 and found median afternoon values equal to $20 \mathrm{ppb}$, though with a wide range of variation.

\section{Conclusions}

We have investigated correlations between ozone and reactive nitrogen in a model of a 1997 event in Mexico City, in contrast with similar results from other cities. These correlations are often linked with model predictions of the response of ozone to reductions in precursor emissions.

Results showed that the model ratio of PAN to $\mathrm{O}_{3}$ is higher than in many other locations, but comparable to model results for Paris. The high PAN relative to $\mathrm{O}_{3}$ is attributed to the relatively low temperature in comparison to other locations during events with elevated $\mathrm{O}_{3}$, which increases the photochemical lifetime of PAN. The model ratio of PAN to $\mathrm{HNO}_{3}$ is unusually high and cannot be explained by temperature. We expect that it reflects the high ratio of $\mathrm{VOC}$ to $\mathrm{NO}_{\mathrm{x}}$ in Mexico City and the high reactivity of VOCs. Measurements show PAN significantly higher than the model values and $\mathrm{HNO}_{3}$ comparable to model values. 
The model predicts that ozone in Mexico City shows mixed sensitivity to $\mathrm{NO}_{\mathrm{x}}$ and VOC, in contrast to model studies of more recent (2003) events (Lei et al., 2007) and measurement-based studies (Stephens et al., 2008) that predicted strongly VOC-sensitive chemistry in Mexico. The difference in predicted $\mathrm{O}_{3}-\mathrm{NO}_{\mathrm{x}}-\mathrm{VOC}$ sensitivity is most likely due to changes in emissions between 1997 and 2003 or to uncertainties in emission rates in general. The difference in sensitivity predictions is associated with differences in predicted ambient $\mathrm{NO}_{\mathrm{x}}$ during the afternoon, which were frequently below $10 \mathrm{ppb}$ in the model used here and 10-90 ppb in the more VOC-sensitive model from Lei et al., 2007. The lower ambient $\mathrm{NO}_{\mathrm{x}}$ may be caused by higher VOC emissions and more rapid conversion from $\mathrm{NO}_{\mathrm{x}}$ to organic nitrates.

Results were also used to explore the relation between ozone-precursor sensitivity and model ambient values of species that might provide a measurement-based test for the accuracy of the sensitivity predictions. $\mathrm{NO}_{\mathrm{x}}$-sensitive conditions were found to be associated with high values of $\mathrm{H}_{2} \mathrm{O}_{2} / \mathrm{HNO}_{3}$ and $\mathrm{O}_{3} / \mathrm{NO}_{\mathrm{y}}$, as has been found for other locations. $\mathrm{NO}_{\mathrm{x}}$-sensitive conditions were also associated with high $\mathrm{O}_{3} / \mathrm{HNO}_{3}$, but the $\mathrm{O}_{3} / \mathrm{HNO}_{3}$ ratio was much higher than in other locations regardless of model $\mathrm{NO}_{\mathrm{x}}$-VOC sensitivity. $\mathrm{O}_{3} / \mathrm{HNO}_{3}$ behaves differently in Mexico City than elsewhere because removal of odd hydrogen radicals is dominated by the formation of PAN and other organic nitrates rather than by the formation of $\mathrm{HNO}_{3}$ and peroxides. This supports the use of some of the measurement-based indicators of ozone sensitivity developed elsewhere $\left(\mathrm{H}_{2} \mathrm{O}_{2} / \mathrm{HNO}_{3}\right.$ and $\mathrm{O}_{3} / \mathrm{NO}_{\mathrm{y}}$ ) by showing that they also apply in a different chemical and meteorological context. However it suggests that caution should be used in interpreting the ratios $\mathrm{O}_{3} / \mathrm{HNO}_{3}$ and $\mathrm{O}_{3} / \mathrm{NO}_{\mathrm{z}}$ as indicators of ozone sensitivity.

These results suggest that long-term measurements of $\mathrm{NO}_{\mathrm{x}}$ and $\mathrm{NO}_{\mathrm{y}}$ might be especially useful in characterizing the ozone-precursor relation in Mexico City.

Acknowledgements. Support for this work was provided by the National Science Foundation grant \#0454838. Any opinions, findings, and conclusions or recommendations expressed in this material are those of the authors and do not necessarily reflect the views of the National Science Foundation.

Edited by: L. Molina

\section{References}

Arriaga-Colina, J. L., West, J. J., Sosa, G., Escalona, S. S., Orduñez, R. M., and Cervantes, A. D. M.: Measurements of VOCs in Mexico City (1992-2001) and evaluation of VOCs and CO in the emissions inventory, Atmos. Environ., 38, 2523-2533, doi:10.1016/j.atmosenv.2004.01.033, 2004.

Chow, J. C., Watson, J. G., Edgerton, S. A., and Vega, E.: Chemical composition of PM2.5 and PM10 in Mexico City during winter 1997, Sci. Total Environ., 287, 177-202, 2002.
Carter, W. P. L.: Documentation of the SAPRC-99 chemical mechanism for VOC reactivity, final report to California Air Resources Board, Contract 92-329 and 95-308, Calif. Air Res. Board, Sacramento, CA, 2000.

Cantrell, C. A., Lind, J. A., Shetter, R. E., Calvert, J. G., Goldan, P. D., Kuster, W., Fehsenfeld, F. C., Montzka, S. A., Parrish, D. D., Williams, E. J. , Buhr, M. P., Westberg, H. H., Allwine, G., and Martin, R.: Peroxy radicals in the ROSE experiment: Measurement and theory, J. Geophys. Res., 97, 20671-20686, doi:10.1029/92JD01727, 1992.

Fast, J. D. and Zhong, S.: Meteorological factors associated with inhomogeneous ozone concentrations within the Mexico City basin, J. Geophys. Res., 103(D15), 18927-18946, 1998.

Gaffney, J. S., Marley, N. A., Cunningham, M. N., and Doskey, P. V.: Measurements of peroxyacyl nitrates (PANS) in Mexico City: Implications for megacity air quality impacts on regional scales, Atmos. Environ., 33, 5003-5012, 1999.

Gao, D., Stockwell, W. R., and Milford, J. B.: Global uncertainty analysis of a regional-scale gas phase chemical mechanism, J. Geophys. Res., 101, 9071-9078, 1996.

Kleinman, L. I., Daum, P. H., Lee, J. H., Lee, Y.-N., Nunnermacker, L. J., Springston, S. R., Newman, L., Weinstein-Lloyd, J., and Sillman, S.: Dependence of ozone production on NO and hydrocarbons in the troposphere, Geophys. Res. Lett., 24, 2299-2302, 1997.

Kleinman, L. I., Daum, P. H., Lee, Y.-N., Nunnermacker, L. J., Springston, S. R., Newman, L., Weinstein-Lloyd, J., and Rudolph, J.: A comparative study of ozone production in five US metropolitan areas, J. Geophys. Res., 110, D02301, doi:10.1029/2004JD005096, 2005.

Kleinman, L. I.: The dependence of tropospheric ozone production rate on ozone precursors, Atmos. Environ., 39, 575-586, 2005.

Lei, W., de Foy, B., Zavala, M., Volkamer, R., and Molina, L. T.: Characterizing ozone production in the Mexico City Metropolitan Area: a case study using a chemical transport model, Atmos. Chem. Phys., 7, 1347-1366, 2007, http://www.atmos-chem-phys.net/7/1347/2007/.

Lei, W., Zavala, M., de Foy, B., Volkamer, R., and Molina, L. T.: Characterizing ozone production and response under different meteorological conditions in Mexico City, Atmos. Chem. Phys., 8, 7571-7581, 2008, http://www.atmos-chem-phys.net/8/7571/2008/.

Marley, N. A., Gaffney, J. S., Ramos-Villegas, R., and Cárdenas González, B.: Comparison of measurements of peroxyacyl nitrates and primary carbonaceous aerosol concentrations in Mexico City determined in 1997 and 2003, Atmos. Chem. Phys., 7, 2277-2285, 2007, http://www.atmos-chem-phys.net/7/2277/2007/.

McKeen, S. A., Hsie, E.-Y., and Liu, S. C.: A study of the dependence of rural ozone on ozone precursors in the eastern United States, J. Geophys. Res., 96, 15377-15394, 1991.

Milford, J., Gao, D., Sillman, S. , Blossey, P., and Russell, A. G.: Total reactive nitrogen (NOy) as an indicator for the sensitivity of ozone to $\mathrm{NO}_{\mathrm{x}}$ and hydrocarbons, J. Geophys. Res., 99, 35333542, 1994.

Molina, L. T., Kolb, C. E., de Foy, B., Lamb, B. K., Brune, W. H., Jimenez, J. L., Ramos-Villegas, R., Sarmiento, J., ParamoFigueroa, V. H., Cardenas, B., Gutierrez-Avedoy, V., and Molina, M. J.: Air quality in North America's most populous city - 
overview of the MCMA-2003 campaign, Atmos. Chem. Phys., 7, 2447-2473, 2007,

http://www.atmos-chem-phys.net/7/2447/2007/.

Nunnermacker, L. J., Weinstein-Lloyd, J. B., Hillery, B., Giebel, B., Kleinman, L. I., Springston, S. R., Daum, P. H., Gaffney, J., Marley, N., and Huey, G.: Aircraft and ground-based measurements of hydroperoxides during the 2006 MILAGRO field campaign, Atmos. Chem. Phys., 8, 7619-7636, 2008, http://www.atmos-chem-phys.net/8/7619/2008/.

Olszyna, K. J., Bailey, E. M., Simonaitis, R., and Meagher, J. F.: $\mathrm{O}_{3}$ and $\mathrm{NO}_{\mathrm{y}}$ relationships at a rural site, J. Geophys. Res., 99, 14557-14563, 1994.

Pierce, T., Geron, C., Bender, L., Dennis, R., Tonnesen, G., and Guenther, A.: Influence of increased isoprene emissions on regional ozone modeling, J. Geophys. Res., 103(D19), 2561125629, 1998.

Roberts, J. M., Williams, J., Baumann, K., et al.: Measurements of PAN, PPN, and MPAN made during the 1994 and 1995 Nashville Intensives of the Southern Oxidant Study: Implications for regional ozone production from biogenic hydrocarbons, J. Geophys. Res., 103(D17), 22473-22490, 1998.

Sander, R., Keene, W. C., Pszenny, A. A. P., Arimoto, R., Ayers, G. P., Baboukas, E., Cainey, J. M., Crutzen, P. J., Duce, R. A., Hönninger, G., Huebert, B. J., Maenhaut, W., Mihalopoulos, N., Turekian, V. C., and Van Dingenen, R.: Inorganic bromine in the marine boundary layer: a critical review, Atmos. Chem. Phys., 3, 1301-1336, 2003, http://www.atmos-chem-phys.net/3/1301/2003/.

Shirley, T. R., Brune, W. H., Ren, X., Mao, J., Lesher, R., Cardenas, B., Volkamer, R., Molina, L. T., Molina, M. J., Lamb, B., Velasco, E., Jobson, T., and Alexander, M.: Atmospheric oxidation in the Mexico City Metropolitan Area (MCMA) during April 2003, Atmos. Chem. Phys., 6, 2753-2765, 2006, http://www.atmos-chem-phys.net/6/2753/2006/.

Sillman, S.: The use of $\mathrm{NO}_{y}, \mathrm{H}_{2} \mathrm{O}_{2}$ and $\mathrm{HNO}_{3}$ as indicators for $\mathrm{O}_{3}-\mathrm{NO}_{\mathrm{x}}$-VOC sensitivity in urban locations, J. Geophys. Res., 100, 14175-14188, 1995.

Sillman, S., Logan, J. A., and Wofsy, S. C.: The sensitivity of ozone to nitrogen oxides and hydrocarbons in regional ozone episodes, J. Geophys. Res., 95, 1837-1851, 1990.

Sillman, S., He, D., Pippin, M. R., Daum, P. H., Imre, D. G., Kleinman, L. I., Lee, J. H., and Weinstein-Lloyd, J.: Model correlations for ozone, reactive nitrogen and peroxides for Nashville in comparison with measurements: implications for $\mathrm{VOC}^{-\mathrm{NO}_{\mathrm{x}}}$ sensitivity, J. Geophys. Res., 103, 22629-22644, 1998.

Sillman, S. and He, D.: Some theoretical results concerning $\mathrm{O}_{3}$ $\mathrm{NO}_{\mathrm{x}}$-VOC chemistry and $\mathrm{NO}_{\mathrm{x}}$-VOC indicators, J. Geophys. Res., 107(D22), 4659, doi:10.1029/2001JD001123, 2002.
Sillman, S., Vautard, R., Menut, L., and Kley, D.: $\mathrm{O}_{3}-\mathrm{NO}_{\mathrm{x}}-\mathrm{VOC}$ sensitivity and $\mathrm{NO}_{\mathrm{x}}$-VOC indicators in Paris: results from models and ESQUIF measurements, J. Geophys. Res., 108, 8563, doi:10.1029/2002JD001561, 2003.

Stephens, S., Madronich, S., Wu, F., Olson, J. B., Ramos, R., Retama, A., and Muñoz, R.: Weekly patterns of México City's surface concentrations of $\mathrm{CO}, \mathrm{NO}_{\mathrm{x}}, \mathrm{PM}_{10}$ and $\mathrm{O}_{3}$ during 19862007, Atmos. Chem. Phys., 8, 5313-5325, 2008 , http://www.atmos-chem-phys.net/8/5313/2008/.

Thornton, J. A., Wooldridge, P. J., Cohen, R. C., et al.: Ozone production rates as a function of $\mathrm{NO}_{\mathrm{x}}$ abundances and $\mathrm{HO}_{\mathrm{x}}$ production rates in the Nashville urban plume, J. Geophys. Res., 107(D12), 4146, doi:10.1029/2001JD000932, 2002.

Trainer, M., Parrish, D. D., Buhr, M. P., Norton, R. B., Fehsenfeld, F. C., Anlauf, K. G., Bottenheim, J. W., Tang, Y. Z., Wiebe, H. A., Roberts, J. M., Tanner, R. L., Newman, L., Bowersox, V. C., Maugher, J. M., Olszyna, K. J., Rodgers M. O., Wang, T., Berresheim, H., and Demerjian, K.: Correlation of ozone with $\mathrm{NO}_{\mathrm{y}}$ in photochemically aged air, J. Geophys. Res., 98, 29172926, 1993.

Velasco, E., Lamb, B., Pressley, S., Allwine, E., Westberg, H., Jobson, B. T., Alexander, M., Prazeller, P., Molina, L., and Molina, M.: Flux measurements of volatile organic compounds from an urban landscape, Geophys. Res. Lett., 32, L20802, doi:10.1029/2005GL023356, 2005.

Velasco, E., Lamb, B., Westberg, H., Allwine, E., Sosa, G., ArriagaColina, J. L., Jobson, B. T., Alexander, M. L., Prazeller, P., Knighton, W. B., Rogers, T. M., Grutter, M., Herndon, S. C., Kolb, C. E., Zavala, M., de Foy, B., Volkamer, R., Molina, L. T., and Molina, M. J.: Distribution, magnitudes, reactivities, ratios and diurnal patterns of volatile organic compounds in the Valley of Mexico during the MCMA 2002 \& 2003 field campaigns, Atmos. Chem. Phys., 7, 329-353, 2007, http://www.atmos-chem-phys.net/7/329/2007/.

Volkamer, R., Sheehy, P. M., Molina, L. T., and Molina, M. J.: Oxidative capacity of the Mexico City atmosphere - Part 1: A radical source perspective, Atmos. Chem. Phys. Discuss., 7, 53655412, 2007, http://www.atmos-chem-phys-discuss.net/7/5365/2007/.

West, J. J., Zavala, M. A., Molina, L. T., Molina, M. J., San Martini, F., McRae, G. J., Sosa-Iglesias, G., and Arriaga-Colina, J. L.: Modeling ozone photochemistry and evaluation of hydrocarbon emissions in the Mexico City metropolitan area, J. Geophys. Res., 109, D19312, doi:10.1029/2004JD004614. 2004.

Zavala, M., Lei, W., Molina, M. J., and Molina, L. T.: Modeled and observed ozone sensitivity to mobile-source emissions in Mexico City, Atmos. Chem. Phys., 9, 39-55, 2009,

http://www.atmos-chem-phys.net/9/39/2009/. 